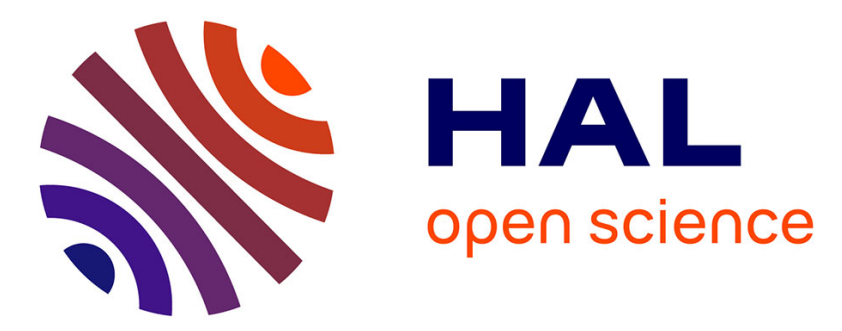

\title{
CO2 capture from coalbed methane using membranes: a review
}

\author{
Na Zhang, Zhen Pan, Zhien Zhang, Wenxiang Zhang, Li Zhang, Francisco M \\ Baena-Moreno, Eric Lichtfouse
}

\section{- To cite this version:}

Na Zhang, Zhen Pan, Zhien Zhang, Wenxiang Zhang, Li Zhang, et al.. CO2 capture from coalbed methane using membranes: a review. Environmental Chemistry Letters, 2019, 18, pp.79 - 96. 10.1007/s10311-019-00919-4 . hal-03139539

\section{HAL Id: hal-03139539 \\ https://hal.science/hal-03139539}

Submitted on 12 Feb 2021

HAL is a multi-disciplinary open access archive for the deposit and dissemination of scientific research documents, whether they are published or not. The documents may come from teaching and research institutions in France or abroad, or from public or private research centers.
L'archive ouverte pluridisciplinaire HAL, est destinée au dépôt et à la diffusion de documents scientifiques de niveau recherche, publiés ou non, émanant des établissements d'enseignement et de recherche français ou étrangers, des laboratoires publics ou privés. 


\title{
$\mathrm{CO}_{2}$ capture from coalbed methane using membranes: a review
}

\author{
Na Zhang ${ }^{1} \cdot$ Zhen Pan $^{1} \cdot$ Zhien Zhang $^{2}\left(\mathbb{D} \cdot\right.$ Wenxiang Zhang ${ }^{3} \cdot$ Li Zhang $^{1} \cdot$ Francisco M. Baena-Moreno ${ }^{4}$. \\ Eric Lichtfouse ${ }^{5}$ (i)
}

\begin{abstract}
Coalbed methane is an abundant form of natural gas extracted from coal beds. Coalbed methane is viewed as a cleaner energy source versus petroleum and coal combustion because methane extraction, transport and use are more efficient and less polluting. However, coalbed methane contains high amounts of $\mathrm{CO}_{2}$ that induce solidification during liquefaction. Therefore, $\mathrm{CO}_{2}$ has to be reduced below $2 \%$ to meet the pipeline transportation standards. In addition, $\mathrm{CO}_{2}$ capture would reduce the amount of gas emissions to the atmosphere, thus mitigating global warming. Here, we review membrane absorption, which is an advanced method for $\mathrm{CO}_{2}$ capture from coalbed methane, by controlling the gas and liquid phases separately during the operation process. We compare $\mathrm{CO}_{2}$ removal methods for various coalbed methane sources. Parameters influencing $\mathrm{CO}_{2}$ removal by membrane absorption are discussed to conclude that $\mathrm{CO}_{2}$ capture efficiency is improved by increasing the flow rate, temperature, and absorbent concentration, reducing the gas flow rate, and selecting a mixed absorbent. We also explain the principles, processes and applications of $\mathrm{CO}_{2}$ membrane absorption.
\end{abstract}

Keywords Coalbed methane $\cdot \mathrm{CO}_{2}$ capture $\cdot$ Membrane $\cdot$ Absorption $\cdot$ Greenhouse effect

\section{Introduction}

Coalbed methane is a clean energy source, but accidental discharge into the atmosphere wastes resources, and induces serious climate warming, threatening the environment and human living conditions (Huang et al. 2018). With the increasing $\mathrm{CO}_{2}$ emissions, the greenhouse effect

Zhen Pan

zhenpan_fs@hotmail.com

Zhien Zhang

zhang.4528@osu.edu

1 College of Petroleum Engineering, Liaoning Shihua University, Fushun, China

2 William G. Lowrie Department of Chemical and Biomolecular Engineering, The Ohio State University, Columbus, USA

3 Department of Civil and Environmental Engineering, Faculty of Science and Technology, University of Macau, Macau, China

4 Chemical and Environmental Engineering Department, Technical School of Engineering, University of Seville, Seville, Spain

5 Aix Marseille Univ, CNRS, IRD, INRA, Coll France, CEREGE, Aix-en-Provence, France is increasing, and carbon dioxide capture has been recognized as a viable option to reduce carbon dioxide (Yan and Zhang 2019). Currently, the methods for $\mathrm{CO}_{2}$ capture mainly include solvent absorption, adsorption, low-temperature distillation, synthetic hydrates, and membranes (Huang et al. 2018; Lv et al. 2012b).

With the changing energy economy in recent years, the consumption of naturally occurring gas has been increasing. Because petroleum and coal are rather exhaustible resources, a production peak is expected in the future. Thus, coalbed methane, which is a high-quality energy source, has been continuously produced ( $\mathrm{Li}$ et al. 2018a, b). China is rich in coal resources and has the third largest coalbed methane reserve in the world after Russia and Canada (Li et al. 2018c; $\mathrm{Su}$ et al. 2018). The world's geological coalbed methane resources amount to approximately $2.68 \times 10^{14} \mathrm{~m}^{3}$. Russia, the USA, China, Canada, and Australia account for 90 vol $\%$ of the world's total coalbed methane resources (China: 12 vol.\%) (Liu et al. 2018c; Su et al. 2018).

The concentration of $\mathrm{CH}_{4}$ in coalbed methane is about 97\% (Mallick and Prabu 2017), and the energy released by combustion of $1 \mathrm{~m}^{3} \mathrm{CH}_{4}$ is 35.9 million $\mathrm{J}$, which is equivalent to the combustion of $1.2 \mathrm{~kg}$ of standard coal (Hao et al. 2018). However, when directly discharged into air by 
accident or negligence, $\mathrm{CH}_{4}$ produces a huge greenhouse effect, which is approximately 21 times stronger than that of $\mathrm{CO}_{2}$. Also the $\mathrm{CH}_{4}$ destructive capacity of the ozone layer is approximately seven times higher than $\mathrm{CO}_{2}$ (Daeho 2018; Warmuzinski 2008). Moreover, other problems are caused, such as increasing surface temperature, frequent climate variations, and aggravating greenhouse effects (Kim and Kim 2018; Lewis et al. 2011; Li et al. 2018a; Luis et al. 2012). Therefore, accidental coalbed methane emissions have caused widespread concern worldwide.

Figure 1a presents the coalbed methane productions of the world's major coalbed methane producers from 2006 to 2014, showing an increase in China. Figure $1 \mathrm{~b}$ depicts the production and utilization of coalbed methane in China from 2011 to 2017 (Zheng and Zhao 2018). Although China's annual coalbed methane production is very high, the utilization rate is relatively low.

Since 2008, China's coalbed methane production has increased significantly to more than $2.832 \times 10^{8} \mathrm{~m}^{3} / \mathrm{a}$ (a: annually, per year) (Moore 2012). The development of coalbed methane is essential for improving the safety of the domestic coal mine production, relieving the market gas supply pressure, and protecting the ecological environment (Qin and Ye 2015). The development of coalbed methane resources not only reduces the emissions of greenhouse gases and ensures an optimized energy exploitation, but also reduces natural disasters such as explosions and spontaneous combustions (Cheng et al. 2017; Fan et al. 2017). As a consequence, China has introduced several policies to promote the development of the coalbed methane industry within the National Thirteenth Five-Year Plan. The Chinese national energy administration has established a strategic goal to achieve a coalbed methane production of $2.40 \times 10^{10}$ $\mathrm{m}^{3}$ in 2020 to accelerate the cultivation and development of the coalbed methane industry and to promote a clean energy production and consumption revolution (Kim et al. 2017; Li et al. 2018a; Sarhosis et al. 2016; Zhou et al. 2014).

Figure 2 shows the storage state of coalbed methane in the ground and its extraction and separation processes (Liu et al. 2018a). Significant progress has been made in the construction of pipelines for coalbed methane in China, with a capacity of more than $4300 \mathrm{~km}$ and 18 billion cubic meters per year (https://www.in-en.com/article/html/energy-2258091.shtml). However, the high amounts of $\mathrm{CO}_{2}$ in the coalbed methane exploitation cause a solidification in subsequent liquefaction. This affects the natural gas treatment process and the quality of the natural gas. Therefore, a coalbed methane decarburization is necessary to reduce the $\mathrm{CO}_{2}$ concentration to values below $2 \%$ to meet the pipeline transportation standard (Bhadra and Farooq 2011; Datta and Sen 2006; Xu et al. 2018).

$\mathrm{CO}_{2}$ capture from other gas mixtures by hollow fiber membrane absorption, and other methods for methane decarburization methods have been reported (Chen and Cui 2012;
Coalbed methane production (bcm)

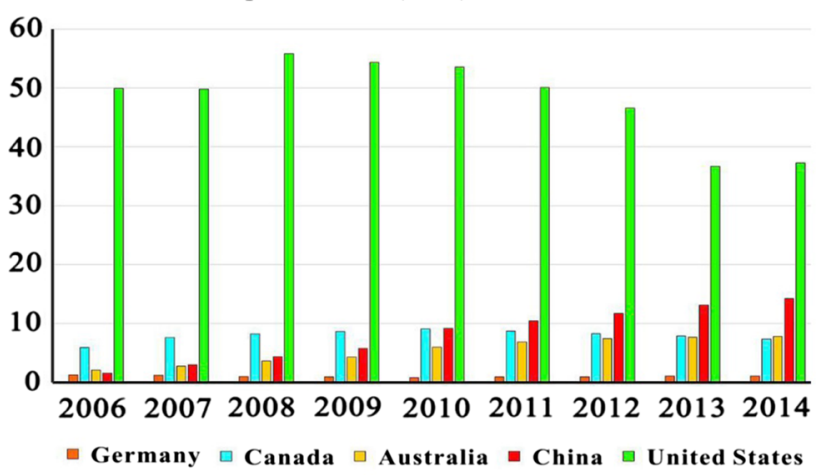

(a)

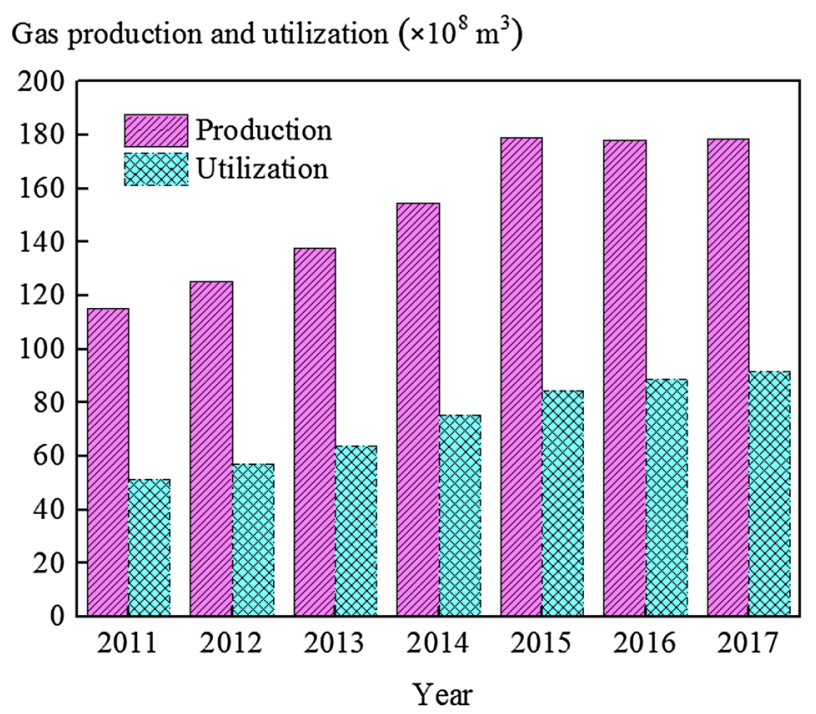

(b)

Fig. 1 a Gas production of the world's major coalbed methane-producing countries. The coalbed methane production in the USA far exceeds that of the other four countries, and the coalbed methane production in China exhibits an upward trend (bcm: billion cubic meters). Reproduced from Ju et al. (2019), with permission from Elsevier; b China's coalbed methane extraction and utilization from 2011 to 2017. With the continuous development and utilization of energy, the utilization of coalbed methane has shown an increasing trend

Fan et al. 2018; Fang et al. 2019; Lee et al. 2019; Li et al. 2019). However, to the best of our knowledge, coalbed methane decarburization by membrane absorption has been rarely reported. For instance, Yan et al. (2015b) studied the use of membrane absorption in flue gas decarburization. They mainly investigated the effect of the membrane structure and various influencing factors on the decarburization efficiency. Anand et al. (2002) investigated the decarburization process of biogas by membrane absorption. However, these studies have not focused on coalbed methane decarburization.

Here, we explore the feasibility of using hollow fiber membrane absorption to remove $\mathrm{CO}_{2}$ from coalbed methane. We 


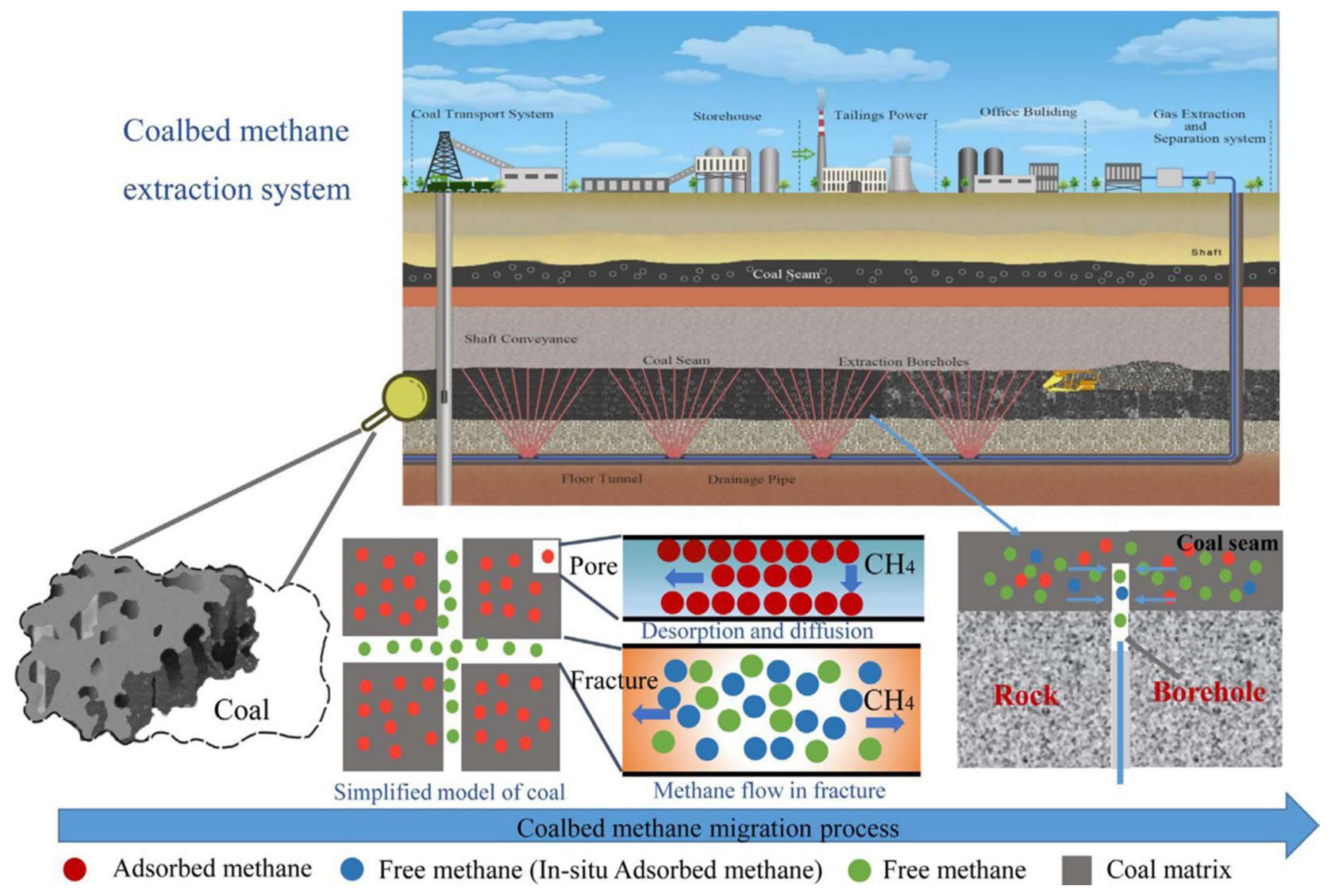

Fig. 2 Coalbed methane production. As the coal is mined, coalbed methane is separated from coal. Coalbed methane is used after pipeline transportation and decarburization. Reproduced from Liu et al. (2018a), with permission from Elsevier

present applications and methods for membrane absorption in decarburization systems. For example, a mathematical model is used to determine how the membrane absorption method changes the decarburization efficiency. This method improves decarburization and acid gas removal versus conventional methods (Zhang et al. 2014b). Then, the " $\mathrm{CO}_{2}$ capture technology for coalbed methane" section compares methods for the capture of $\mathrm{CO}_{2}$ from coalbed methane. In the " $\mathrm{CO}_{2}$ capture by membrane absorption" section, the principles of the membrane absorption and the main factors controlling the capture of $\mathrm{CO}_{2}$ are discussed. Furthermore, the application of membrane absorption to other gases is reported in "Membrance absorption applied to other gases" section.

\section{$\mathrm{CO}_{2}$ capture technology for coalbed methane}

Currently, the methods for removing $\mathrm{CO}_{2}$ from coalbed methane mainly include solvent absorption, adsorption, low-temperature distillation, synthetic hydrates, and membranes (Table 1). Solvent absorption is a gas separation technology that separates the components with the highest solubilities from a mixture with a liquid absorbent (Chen and Wen 2015). Lei and Yao (2013) added different additives (piperazine, ethanolamine, and diethanolamine) to methyl diethanolamine to capture $\mathrm{CO}_{2}$ from coalbed methane. The results show that the absorption performance of the methyl diethanolamine solution increases highly after the addition of the additives. However, the regeneration ability of the mixed solution decreases to a certain extent because the regeneration performance of the additives is lower than that of methyl diethanolamine. Furthermore, it was discovered that diethanolamine has a better absorption performance than methyl diethanolamine and a better regeneration performance than ethanolamine.

Wan (2014) simulated the decarburization process of coalbed methane with methyl diethanolamine in an absorption tower and analyzed the effect of the pristine and activated methyl diethanolamine concentration on the $\mathrm{CO}_{2}$ capture efficiency of the system. The results show that the larger the mass fraction of the methyl diethanolamine solution, the stronger the decarburization efficiency. Zhang et al. (2019) modeled the decarburization of coalbed methane 
with four amine solutions, i.e., diethanolamine, ethanolamine, triethanolamine, and 1-(2-hydroxyethyl) pyrrolidine. 1-(2-Hydroxyethyl) pyrrolidine induces a high decarburization efficiency even at low absorbent concentrations because it exhibits a high chemical reaction constant for $\mathrm{CO}_{2}$. When the 1-(2-hydroxyethyl) pyrrolidine concentration increases from 0.4 to $0.9 \mathrm{M}$, its decarburization efficiency increases by $46.9 \%$. Furthermore, Chen and Wen (2015) considered the corrosion and degradation of an amine solution in the coalbed methane decarburization process. The advantages of the solvent absorption method are the simple equipment, low energy consumption, low investment, and high purity of the products. The disadvantages are the slow absorption and regeneration of the solution.

Pressure swing adsorption is the selective adsorption of a separated gas mixture through adsorbents under different partial pressures (Ebner and Ritter 2009). Tao et al. (2019) used a pressure swing adsorption device to remove $\mathrm{CO}_{2}$ from natural gas with a high $\mathrm{CO}_{2}$ content. The decarburization efficiency reaches $66 \%$ for a $\mathrm{CO}_{2}$ content of $30-50 \%$ and pressure of 7 bar. However, the purity of the final product $\mathrm{CH}_{4}$ is insufficient to meet the general natural gas demand. Based on the experimental data of the pressure swing adsorption, they investigated the effects of the pressure with simulations. According to their results, the $\mathrm{CH}_{4}$ purity can reach $98 \%$ when the pressure is reduced to 1 bar. Thus, the pressure is a critical factor for achieving the required separation performance. Engelhard used the Molecular Gate ${ }^{\mathrm{TM}}$ adsorption technology to decarbonize coalbed methane by compressing the feed pressure in a more traditional pressure swing adsorption mode (Ebner and Ritter 2009). Moreover, Daeho (2016) studied the coalbed methane decarburization through vacuum pressure swing adsorption. The advantages are the mature technology, simple equipment, low operating costs, and high methane recovery rate. However, it consumes much energy and strongly depends on the adsorbents.

Cryogenic distillation usually includes a mechanical method to liquefy the gas and exploits the difference in the gas boiling points to conduct the rectification. Thus, the different gas components can be separated and a high-purity gas is obtained (Chen 2017; Lv et al. 2013). Wang et al. (2014) used the cryogenic distillation technology to liquefy and separate components of coalbed methane at low temperatures and pressures simultaneously. For an increase in the methane concentration in the coalbed methane from 22 to $27 \%$, the methane recovery rate increases slightly to approximately $98.7 \%$. For an increase in the methane concentration from 27 to $45 \%$, the methane recovery rate decreased slightly but was still above $98 \%$. Moreover, Sun and Zhu (2009) designed a cryogenic liquefaction separation equipment for coalbed methane with a $50 \%$ air volume and a daily processing capacity of $5.67 \times 10^{4} \mathrm{~m}^{3}$. It simultaneously completes the liquefaction and separation processes and exhibits a $\mathrm{CH}_{4}$ recovery rate of $82.19 \%$. At this stage, cryogenic rectification is a matured technology with a high product purity and $\mathrm{CH}_{4}$ recovery rate. The drawbacks of the method are the high energy consumption, large investment, complex equipment, and unsuitability for low-concentration and small-scale coalbed methane fields.

Hydrate separation of $\mathrm{CO}_{2}$ is a new carbon capture approach (Meng et al. 2018), which exploits the different pressures of the gas components in the mixture to form hydrates in a solution and achieve the separation (Liu et al. 2018b; Pan et al. 2018). The study demonstrates that the required pressures for the $\mathrm{CH}_{4}$ and $\mathrm{CO}_{2}$ hydrate formation are $2.65 \mathrm{MPa}$ and 1.22 MPa under equal conditions, respectively (Wang et al. 2013). Therefore, the $\mathrm{CO}_{2}$ separation from coalbed methane through this method can be achieved by controlling the temperature and pressure. Hence, gas components of $\mathrm{CO}_{2}$ that easily form hydrates can be separated from the gas phase to purify the coalbed methane ( $\mathrm{Lv}$ et al. 2013). In another work (Zhong et al. 2014), the $\mathrm{CH}_{4}$ recovery rate reaches $46.1 \%$ at $283.4 \mathrm{~K}$ and $2.6 \mathrm{MPa}$. After the secondary hydration separation, the $\mathrm{CH}_{4}$ volume fraction increases from 30 to $72 \%$. The key of the coalbed methane hydrate separation technology is to determine the thermodynamic conditions for the separation of different components to improve the separation efficiency. The technology provides a high storage density, convenient transportation, simple process, and oxygen-free products. However, it requires a high operating pressure, constitutes a high safety risk, and exhibits high costs and a low methane recovery rate.

The membrane absorption method has attracted much attention owing to its large gas-liquid contact area, fast mass transfer rate, high operational flexibility, no liquid ubiquity and mist entrainment, and simple equipment (Anand et al. 2002). Compared with traditional separation methods, the membrane absorption method is efficient and requires low investments and maintenance costs for the coalbed methane treatment (Gabelman 1999; Kaldis et al. 2004; Medina-Gonzalez et al. 2012). Zeng et al. (2017) first studied the coalbed methane decarburization by combining pressure swing adsorption and the membrane separation technology. The results show that the $\mathrm{CH}_{4}$ loss rate can be reduced by at least $61.5 \%$ with respect to the loss rates of the individual methods. Daeho (2018) used a hollow fiber membrane with a countercurrent flow structure to absorb $\mathrm{CO}_{2}$ from coalbed methane. The selected coalbed methane composition in the simulations was $90 \% \mathrm{CH}_{4}$ and $10 \% \mathrm{CO}_{2}$. According to the results, increasing the effective length and number of fiber membranes and the gas pressure or decreasing the gas flow rate can improve the $\mathrm{CH}_{4}$ recovery rate and purity. Moreover, Zhang et al. (2019) used a membrane contactor for coalbed methane decarburization by establishing a mathematical model. The results show that the decarburization efficiencies can be 
increased by $30 \%$ and $46 \%$ for an increased liquid flow rate and absorbent concentration, respectively. The decarburization efficiency is significantly better than that of a single membrane contactor (maximal increase of $47 \%$ ). However, the gas mixture only contained $\mathrm{CO}_{2}$ and $\mathrm{CH}_{4}$. Thus, other gas components should be investigated in future studies.

At present, the membrane absorption method is widely applied for natural gas purification because of the high $\mathrm{CH}_{4}$ concentrations in gas streams. Tang et al. (2014) compared the effects of single methyl diethanolamine solutions and its blended solutions with diethylenetriamine or triethylenetetramine on the $\mathrm{CO}_{2}$ absorption capacity during natural gas decarburization. They discovered that the $\mathrm{CO}_{2}$ absorption capacity is enhanced when diethylenetriamine or triethylenetetramine is added. Faiz and Almarzouqi (2010) used hollow fiber membrane contactors to capture $\mathrm{CO}_{2}$ from natural gas at high pressures up to 50 bar with physical and chemical absorbents. In addition, Kang et al. (2017) investigated $\mathrm{CO}_{2}$ capture from natural gas containing $70 \% \mathrm{CO}_{2}$. According to the results, the $\mathrm{CO}_{2}$ capture efficiency increases from 33.3 to $91.3 \%$ when the pressure is increased from 1 to 60 bar. In this study, the capture of high $\mathrm{CO}_{2}$ concentrations from natural gas was investigated with a membrane contactor process at elevated pressures for the first time. Furthermore, AlSaffar et al. (1997) studied the decarburization of natural gas via membrane absorption. The advantages of this technology are the low energy consumption, low operating costs, and no secondary pollution. In addition, the membrane life could hinder further pilot-scaled applications of this technology.

Based on a comparison of multiple coalbed methane decarburization methods, the membrane absorption method exhibits advantages regarding the process flow, energy consumption, operating costs, and decarburization efficiency. Owing to the coalbed methane characteristics, simple development concept, and environmental protection, the membrane absorption method is more suitable for coalbed methane decarburization treatments and will become a hot spot in this research field.

\section{$\mathrm{CO}_{2}$ capture by membrane absorption}

\section{Principle}

The membrane absorption method is a novel separation process that combines membrane separation and absorption. It usually employs microporous membranes. During the process, the gas and liquid phases flow through both sides of the membrane contactor and contact at a fixed gas-liquidphase interface. The membrane itself is not gas selective but acts as a barrier to separate the absorbent and gas. The $\mathrm{CO}_{2}$ diffuses through the membrane to the liquid phase owing to a concentration gradient. Theoretically, the membrane pores allow the $\mathrm{CO}_{2}$ gas molecules to pass the membrane section without a high-pressure driving force. Thereby, one mainly relies on the selective absorption of the absorbent to separate mixed gases (Li and Chen 2005; Liang et al. 2013). The basic principle (for a hydrophobic porous membrane) is shown in Fig. 3a. The main driving force of the technology is the gas concentration difference. First, $\mathrm{CO}_{2}$ from the gas mixture reaches the surface of the membrane pore and diffuses through the membrane pores to the gas-liquid twophase interface. Next, $\mathrm{CO}_{2}$ reacts with the absorbent in the tube side (Boucif et al. 2008; Genceli et al. 2018). After the purification, the $\mathrm{CH}_{4}$ gas in the coalbed methane separates from the gas mixture. Figure $3 \mathrm{~b}$ demonstrates the $\mathrm{CO}_{2}$ separation process from coalbed methane through membrane absorption.

\section{Effect of absorbent type}

The absorbent type in the membrane absorption has an important effect on the $\mathrm{CO}_{2}$ capture from coalbed methane. The absorbent choice should consider the absorption efficiency, mass transfer rate, chemical stability, and recycling performance. In addition, physical properties such as the degradability, toxicity, corrosivity, and volatility of the absorbent and the chemical compatibility with the membrane material must be considered. The development of the $\mathrm{CO}_{2}$ absorbent use is depicted in Table 2.

Although water was used as absorbent owing to the easy access, the method exhibits a low capture efficiency. Afterward, amine solutions were applied worldwide (Amrei et al. 2014; Nakhjiri et al. 2018; Pashaei et al. 2016; Stowe and Hwang 2017; Yuan et al. 2017). Marzouk et al. (2010) conducted an experimental study on $\mathrm{CO}_{2}$ capture in a mixed gas $\left(9.5 \% \mathrm{CO}_{2} / 90.5 \% \mathrm{CH}_{4}\right)$. They compared the effects of water, sodium hydroxide solution, and ethanolamine solution on the $\mathrm{CO}_{2}$ flux and capture efficiency. The results show that both sodium hydroxide solution and ethanolamine solution have higher $\mathrm{CO}_{2}$ flux and capture efficiency than water. Boributh et al. (2013) and Al-Marzouqi et al. (2009) selected water and ethanolamine as absorbents to remove $\mathrm{CO}_{2}$ from mixed gases $\left(10 \% \mathrm{CO}_{2} / 90 \% \mathrm{CH}_{4}\right)$. They concluded that ethanolamine has a better $\mathrm{CO}_{2}$ separation ability than water. Because sodium hydroxide and ethanolamine solutions react chemically with $\mathrm{CO}_{2}$. Hence, their decarburization efficiencies are significantly higher.

Because amine absorbents exhibit volatilization, large losses, high corrosivity, and poor thermal degradation in decarburization processes, their application in the $\mathrm{CO}_{2}$ capture and separation is limited. To improve the compatibility with the membrane materials, amino acid salt solutions are employed in membrane absorption systems (Li et al. 2018c). An amino acid salt solution exhibits the same absorption performance and capacity as an amine absorbent, exhibits a low 
Fig. 3 a $\mathrm{CO}_{2}$ transport in a membrane contactor. The main driving force of the technology is the gas concentration difference. First, $\mathrm{CO}_{2}$ from the gas mixture reaches the surface of the membrane pore and diffuses through the membrane pores to the gas-liquid two-phase interface. Next, $\mathrm{CO}_{2}$ reacts with the absorbent in the tube side; b process flow diagram of gas separation. After the mixed gas is separated by the membrane contactor, the absorbent is subjected to gas-liquid separation treatment to recycle the absorbent. At the same time, the decarburized gas is collected and stored

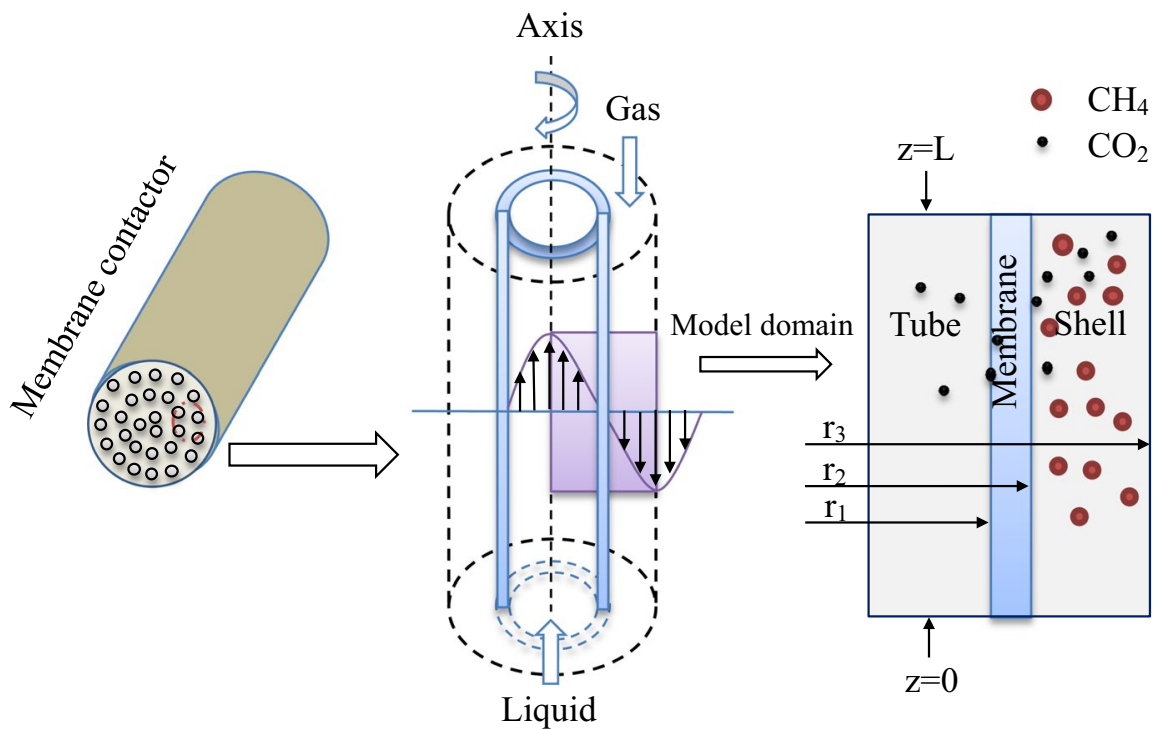

(a)

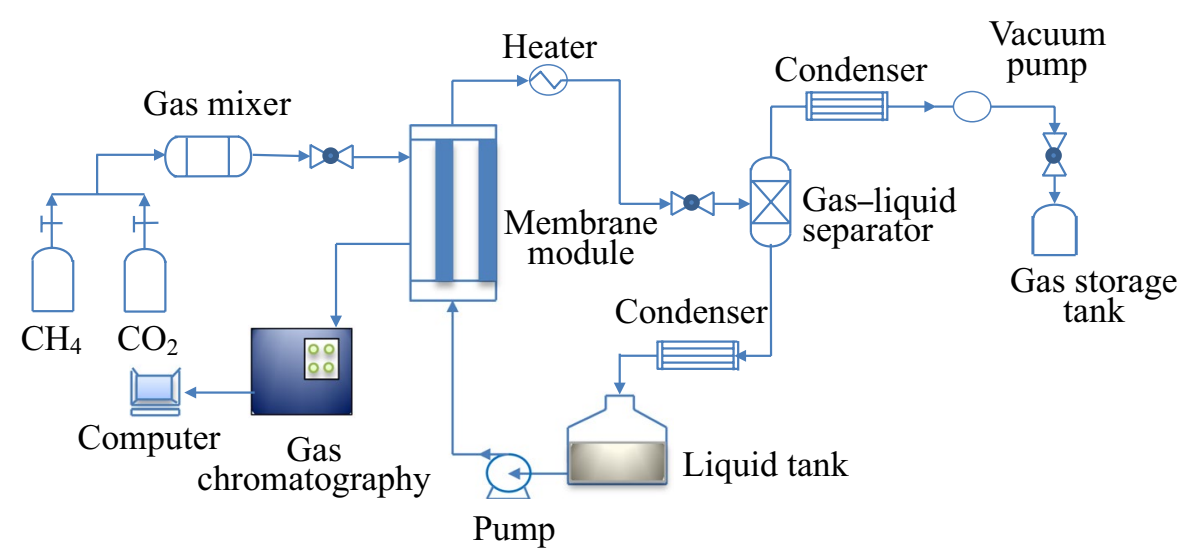

(b) volatility and good resistance to oxidative degradation and thermal degradation (Fang et al. 2015). Rahim et al. (2015) conducted $\mathrm{CO}_{2}$ capture experiments with a gas mixture of $10 \% \mathrm{CO}_{2}$ and $90 \% \mathrm{CH}_{4}$. The experimental results show that the decarburization efficiency of the amino acid salt solution is better than that of the amine solution. Furthermore, Simons et al. (2010) compared the effects of amino acid salt solution and ethanolamine on the decarburization efficiency in a mixed gas $\left(20 \% \mathrm{CO}_{2} / 80 \% \mathrm{CH}_{4}\right)$. The results reveal that amino acid salt solutions exhibit competitive capability in capturing $\mathrm{CO}_{2}$. Moreover, with the rise of nanomaterials, research on the enhancement of $\mathrm{CO}_{2}$ absorption with nanofluids has gradually emerged.

Nanofluids exhibit high absorption efficiency, absorption capacity, thermal conductivity, and stability (Hajilary and Rezakazemi 2018; Kim et al. 2018). Rezakazemi et al. (2019) selected carbon nanotube and $\mathrm{SiO}_{2}$ nanofluids for the separation of $\mathrm{CO}_{2}$. As presented in Fig. 4, the
$\mathrm{CO}_{2}$ separation efficiencies of the carbon nanotubes and $\mathrm{SiO}_{2}$ nanofluids as absorbents are superior to that of water. Taheri et al. (2016) added $\mathrm{SiO}_{2}$ and $\mathrm{Al}_{2} \mathrm{O}_{3}$ nanoparticles to a diethanolamine absorbent to form a nanofluid for the decarburization of mixed $\mathrm{CO}_{2} / \mathrm{CH}_{4}$ gas. The experimental results show that the decarburization efficiency of the $\mathrm{SiO}_{2} /$ diethanolamine nanofluids is $40 \%$ higher than that of a pure diethanolamine solution. Furthermore, the decarburization efficiency of $\mathrm{Al}_{2} \mathrm{O}_{3}$ /diethanolamine nanofluids is increased by $33 \%$. In addition, Zhang et al. (2018a) promotes the $\mathrm{CO}_{2}$ absorption through nanofluids.

Owing to the low regeneration and absorption rate of a single absorbent, researchers have employed mixed solutions as absorbents and achieved great progresses. Zhang and Shu (2014) compared the reproducibility and $\mathrm{CO}_{2}$ absorption properties of sodium glycinate and potassium glycinate by adding triethanolamine. The results show that the addition of low triethanolamine concentrations can increase the 


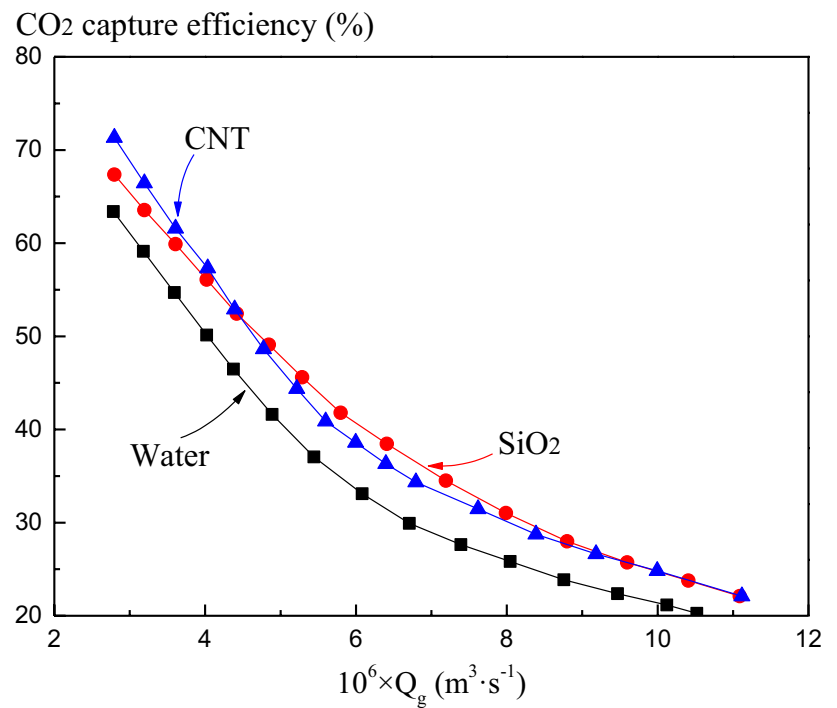

Fig. 4 Effects of gas flow on $\mathrm{CO}_{2}$ capture efficiency of different nanofluids. The $\mathrm{CO}_{2}$ separation efficiencies of the carbon nanotubes (CNT) and $\mathrm{SiO}_{2}$ nanofluids as absorbents are superior to that of water. Reproduced from (Rezakazemi et al. 2019), with permission from Elsevier

$\mathrm{CO}_{2}$ absorption capacity. Moreover, Zhang et al. (2014a, b) employed a mixed methyl diethanolamine/ $\mathrm{N}$-aminoethyl piperazine solution as absorbent and polypropylene hollow fiber membranes to conduct a comprehensive parametric study on the $\mathrm{CO}_{2}$ absorption behavior. According to the results, the $\mathrm{N}$-aminoethyl piperazine and methyl diethanolamine mixture has a higher $\mathrm{CO}_{2}$ absorption capability. Mesbah et al. (2019) developed a mathematical 2D model and used a hollow fiber membrane contactor to separate $\mathrm{CO}_{2}$ from a $\mathrm{CO}_{2} /$ $\mathrm{CH}_{4}$ gas mixture with a mixed solution of 2-methylpiperazine and potassium carbonate as absorbent. They discovered that increasing the 2-methylpiperazine concentration from 0.1 to $0.5 \mathrm{~mol} / \mathrm{L}$ can significantly improve the $\mathrm{CO}_{2}$ capture efficiency (up to $98 \%$ ). Table 3 summarizes the conditions and parameters of the membrane absorption tests conducted in the literature.

According to the previously presented analysis, the mixed solution has a higher absorption efficiency and recycling efficiency when subjected to a decarburization treatment than a single absorbent. This is because the mixed solution can overcome the disadvantages of a single absorbent and concentrates the advantages of different absorbents, thereby improving the absorption efficiency and increasing the absorption capacity.

In summary, the main gas component selected by most researchers is $\mathrm{CH}_{4}$, which is also the main component of coalbed methane. Therefore, the previously mentioned research studies are also applicable to coalbed methane decarburization. In practical applications, different proportions of the solution should be mixed based on the actual needs to achieve a high decarburization efficiency and high reproducibility of the solution.

\section{Effect of gas-phase parameters}

The gas-phase parameters mainly include the gas composition, pressure, and flow rate of coalbed methane. These parameters have a great influence on the absorption process of a $\mathrm{CO}_{2}$ film. Generally, the capture efficiency of $\mathrm{CO}_{2}$ decreases with increasing gas velocity. However, the mass transfer effect works oppositely. This is because the residence time of the gas phase in the membrane decreases sharply. Hence, the boundary layer of the gas phase becomes thinner gradually, and a part of the $\mathrm{CO}_{2}$ is separated from the membrane contactor before fully reacting with the absorbent, which weakens the capture efficiency. Simultaneously, the increase in gas velocity reduces the resistance of the mass transfer process, thus enhancing the mass transfer effect between the gas-liquid reactions. Lv et al. (2012a) studied the capture efficiency of $\mathrm{CO}_{2}$ at different flow rates with a polypropylene hollow fiber membrane module. The results show that the capture efficiency decreases with increasing gas flow rate and increases with increasing absorbent flow rate.

Daeho (2018) used a hollow fiber membrane with a countercurrent flow structure to absorb and remove $\mathrm{CO}_{2}$ from coalbed methane. The composition of the selected coalbed methane in the simulation process was $90 \% \mathrm{CH}_{4}$ and $10 \%$ $\mathrm{CO}_{2}$. According to the numerical simulation results, the purification efficiency of $\mathrm{CH}_{4}$ is inversely proportional to the change in the gas flow rate. Furthermore, Zhang (2016) simulated the effect of the absorbent flow rate on the $\mathrm{CO}_{2}$ capture efficiency. The results show that when the gas flow rate increases from 0.28 to $1.40 \mathrm{~m} / \mathrm{s}$, the $\mathrm{CO}_{2}$ capture efficiency decreases by approximately 50\%. Yan et al. (2007) obtained similar trends with a potassium glycinate solution. Moreover, Zhang et al. (2019) selected coalbed methane $\left(14 \% \mathrm{CH}_{4} / 86 \% \mathrm{CO}_{2}\right.$ ) as feed gas and used an alcohol amine solution to decarbonize coalbed methane. The results show that the $\mathrm{CO}_{2}$ concentration at the membrane outlet increases with increasing gas flow rate. When $0.5 \mathrm{M}$ diethanolamine, ethanolamine, triethanolamine, and 1-(2-hydroxyethyl) pyrrolidine and gas flow rates of $0.3-0.8 \mathrm{~m} / \mathrm{s}$ are applied, the $\mathrm{CO}_{2}$ capture efficiency in the membrane decreases by $55.7 \%$, $51.2 \%, 47.5 \%$, and $59.9 \%$, respectively.

Logically, an increasing system pressure increases the $\mathrm{CO}_{2}$ concentration in the gas phase. However, with increasing gas pressure, the driving force of the mass transfer process increases. Hence, more $\mathrm{CO}_{2}$ molecules can enter the gas-liquid interface through a membrane pore and react with the absorbent, which improves the $\mathrm{CO}_{2}$ capture efficiency (Cozma et al. 2015; Dindore et al. 2004). Mansourizadeh 
et al. (2010) used a polyvinylidene fluoride hollow fiber membrane to absorb $\mathrm{CO}_{2}$ in a mixed gas and analyzed the effect of the gas-phase pressure on the mass transfer. When the $\mathrm{CO}_{2}$ pressure increases from $1 \times 10^{5}$ to $6 \times 10^{5} \mathrm{~Pa}$, the $\mathrm{CO}_{2}$ flux increases from $1.25 \times 10^{-3}$ to $6.5 \times 10^{-3} \mathrm{~mol} / \mathrm{m}^{2} \mathrm{~s}$, and the $\mathrm{CO}_{2}$ capture efficiency increases by $50 \%$. Razavi et al. (2013), Mansourizadeh (2012), and Gao et al. (2018) validated this conclusion in subsequent studies.

The $\mathrm{CO}_{2}$ content in coalbed methane is generally 10-20\%. The higher the $\mathrm{CO}_{2}$ ratio, the thicker the boundary layer of the gas phase, and the diffusion of a large amount of $\mathrm{CO}_{2}$ in the membrane pores is hindered, which decreases the total mass transfer coefficient. Simultaneously, parts of the $\mathrm{CO}_{2}$ and absorbent have not completely reacted and leave the membrane contactor, which results in a decrease in the $\mathrm{CO}_{2}$ capture efficiency. Zhang (2016) studied the effect of the $\mathrm{CO}_{2}$ content on the capture efficiency through simulations. When the $\mathrm{CO}_{2}$ content is increased from 10 to $20 \%$, the decarburization efficiency is reduced by approximately $50 \%$. At constant solubility, the $\mathrm{CO}_{2}$ amount participating in the permeation reaction remains constant, and the amount of $\mathrm{CO}_{2}$ increases. Thus, the decarburization efficiency decreases. Yan et al. (2007) and Chen et al. (2004) obtained the same behavior for the efficiency through experimental studies.

The $\mathrm{CH}_{4}$ content in coalbed methane is $86-97 \%$ (Flores and Flores 2014; Mallick and Prabu 2017; Zhang et al. 2019). Because of the low $\mathrm{CO}_{2}$ content in the initial stage of coalbed methane mining, coalbed methane can be directly burned. However, as the $\mathrm{CO}_{2}$ content in coalbed methane continues to increase, hydrated solids block the pipeline when low temperatures and high pressures are encountered during the pipeline transportation. To improve the utilization efficiency of coalbed methane and reduce safety hazards in the transportation process, a decarburization treatment is required. As mentioned above, the coalbed methane decarburization efficiency can be improved by increasing the gas-phase pressure, reducing the gas flow rate and the percentage of $\mathrm{CO}_{2}$ during the coalbed methane decarburization treatment.

\section{Effect of liquid-phase parameters}

Liquid-phase parameters play a key role in the improvement in the $\mathrm{CO}_{2}$ capture efficiency. The effects of the $\mathrm{CO}_{2}$ capture efficiency on the liquid concentration, flow rate, and temperature are summarized in this section. According to the two-phase theory, the $\mathrm{CO}_{2}$ absorption mainly occurs in the liquid-phase boundary layer (Lewis et al. 2011). Starting from the shell side, $\mathrm{CO}_{2}$ enters the liquid-phase boundary layer through the membrane pores and is quickly absorbed by the absorption liquid. As the concentration of the absorbing liquid increases, the concentration of the active component that absorbs $\mathrm{CO}_{2}$ in the boundary layer of the liquid phase increases. This can increase the chemical reaction rate of $\mathrm{CO}_{2}$ and the solute dissolved in the liquid phase (Yan et al. 2014a). Hence, the $\mathrm{CO}_{2}$ concentration in the liquid film is rapidly decreased, and the liquid film resistance is lowered, which improves the $\mathrm{CO}_{2}$ removal efficiency. Zhang (2016) studied the effect of the changing absorbent concentration on the $\mathrm{CO}_{2}$ capture efficiency through experiments. The results show that when the concentration of the absorbent increases from 0.1 to $1 \mathrm{~mol} / \mathrm{L}$, the $\mathrm{CO}_{2}$ capture efficiency is increased by $61.8 \%$. Eslami et al. (2011) used numerical models to study the effect of different concentrations of a potassium glycinate solution on the $\mathrm{CO}_{2}$ capture efficiency in polytetrafluoroethylene hollow fiber membrane contactors. According to their results, when the absorbent concentration is increased from 0.5 to $3 \mathrm{M}$, the $\mathrm{CO}_{2}$ capture efficiency is increased by approximately $14 \%$.

With increasing absorbent flow rate, the disturbance of the liquid in the tube is strengthened, the thickness of the boundary layer is reduced, the mass transfer resistance of the liquid phase is reduced, and more fresh absorbents react with the $\mathrm{CO}_{2}$ molecules. Thus, the decarburization efficiency is improved (Zhang et al. 2019). Zhang (2016) simulated the effect of the absorbent flow rate on the $\mathrm{CO}_{2}$ capture efficiency. The results show that when the absorbent flow rate increases from 0.015 to $0.085 \mathrm{~m} / \mathrm{s}$, the $\mathrm{CO}_{2}$ capture efficiency increases by approximately $30 \%$. Lv et al. (2012a) used $0.5 \mathrm{~mol} / \mathrm{L}$ ethanolamine to capture $\mathrm{CO}_{2}$ with polypropylene hollow fiber membranes. The effect of the liquidphase flow on the absorption performance for $8-46 \mathrm{~mL} / \mathrm{min}$ was studied at a constant feed gas flow. The results show that when the liquid-phase flow rate is increased, the $\mathrm{CO}_{2}$ capture efficiency increases by $49 \%$. This conclusion has been verified in subsequent studies (Ansaripour et al. 2018).

In addition to increasing the flow rate of the absorbent, increasing the absorbent temperature helps to increase the $\mathrm{CO}_{2}$ absorption efficiency (Eslami et al. 2011; Yan et al. 2007). Shirazian et al. (2009) compared the decarburization rate of an absorbent at $298 \mathrm{~K}$ and $288 \mathrm{~K}$. The decarburization rate increases by approximately $10 \%$ with the increase in temperature. Moreover, Mansourizadeh et al. (2010) studied the effect of absorbent temperature on $\mathrm{CO}_{2}$ capture efficiency. When the absorbent temperature was increased from 283 to $313 \mathrm{~K}$, the $\mathrm{CO}_{2}$ mass transfer rate was increased by approximately 58.6\%. Wu et al. (2012) studied the effect of changes in the absorbent temperature on the $\mathrm{CO}_{2}$ capture efficiency and mass transfer rate. When the absorption temperature is increased from 298 to $325 \mathrm{~K}$, the $\mathrm{CO}_{2}$ capture rate and mass transfer rate are increased by $30 \%$ and $40 \%$, respectively.

According to the previous analysis, increasing the concentration, flow rate, and absorbent temperature can improve the $\mathrm{CO}_{2}$ capture efficiency. However, owing to the required temperature control for the membrane material in 
the membrane contactor while the absorbent temperature is being changed, the actual material characteristics should be controlled to maximize the capture efficiency.

\section{Effect of membrane contactor structure}

At present, there is no study focusing on the effect of the membrane contactor structure on the $\mathrm{CO}_{2}$ capture from coalbed methane. The main components of coalbed methane and natural gas are $\mathrm{CH}_{4}$ and $\mathrm{CO}_{2}$, whereas the main components of flue gas are $\mathrm{N}_{2}$ and $\mathrm{CO}_{2}$. Although their compositions are slightly different, the common essence is the removal of $\mathrm{CO}_{2}$ from the mixture. The research on the impact of membrane contactor structures on $\mathrm{CO}_{2}$ removal from flue gas is relatively mature which provides guidelines in the $\mathrm{CO}_{2}$ separation from coalbed methane. Figure 5 presents the structure of a hollow fiber membrane contactor (Zhang 2015).

Changes in the wall thickness of the fiber membrane affect the direction of the gas movement. Furthermore, increasing the wall thickness prolongs the residence time of the gas in the membrane, thereby increasing the resistance along the path, which makes the diffusion movement more complicated and leads to a decrease in the decarburization efficiency (Rezakazemi et al. 2011). Yan et al. (2015b) studied the effect of the fiber wall thickness on the $\mathrm{CO}_{2}$ capture efficiency. The results show that the $\mathrm{CO}_{2}$ capture efficiency decreases with increasing wall thickness. Furthermore, the decarburization efficiency is reduced by approximately $40 \%$ owing to the weak reaction between diethanolamine and $\mathrm{CO}_{2}$. Rezakazemi et al. (2011) reported the same conclusions.

Increasing the effective length of the fiber membrane increases the gas-liquid contact area, which results in a prolonged residence time of the gas in the membrane. Consequently, the $\mathrm{CO}_{2}$ capture process in the gas is enhanced.
Boributh et al. (2011) selected three different membrane lengths $(0.25 \mathrm{~m}, 0.5 \mathrm{~m}$, and $0.7 \mathrm{~m})$ to compare their $\mathrm{CO}_{2}$ capture efficiencies. The results show that the decarburization efficiencies for a membrane length of $0.7 \mathrm{~m}$ increase by $15.27 \%(0.25 \mathrm{~m})$ and $3.58 \%(0.5 \mathrm{~m})$, respectively.

Reducing the inner diameter of the fiber membrane increases the flow rate of the absorbent, which results in an increase in the $\mathrm{CO}_{2}$ absorption per unit time and in an improvement in the $\mathrm{CO}_{2}$ capture efficiency. Rajabzadeh et al. (2009) studied the effect of a changing inner membrane diameter on the $\mathrm{CO}_{2}$ capture efficiency. According to the results, the capture efficiency increases with decreasing inner membrane diameter because the gas-liquid two-phase contact area increases with increasing number of hollow fiber membranes. This results in an increase in the packing density and shell-side mass transfer coefficient. Eslami et al. (2011) investigated the effects on the $\mathrm{CO}_{2}$ capture efficiency for a liquid flow rate of $0.1 \mathrm{~m} / \mathrm{s}$, an absorbent concentration of $0.5 \mathrm{~mol} / \mathrm{L}$, and increasing number of hollow fiber membranes from 3000 to 10,000 . As a result, the capture efficiency increases from 36 to $100 \%$. Furthermore, Faiz and Almarzouqi (2010) used a membrane contactor to remove $\mathrm{CO}_{2}$ from natural gas under high pressure. The results show that the capture efficiency increases with increasing porosity and decreases with increasing tortuosity factor.

According to the previous analysis, to ensure the overall performance of the membrane module, reducing the wall thickness of the membrane, the inner diameter, and tortuosity factor and increasing the number of membranes, porosity, and effective membrane length are beneficial to the $\mathrm{CO}_{2}$ capture. The $\mathrm{CO}_{2}$ capture from coalbed methane through membrane contactor structures will be the future research direction.

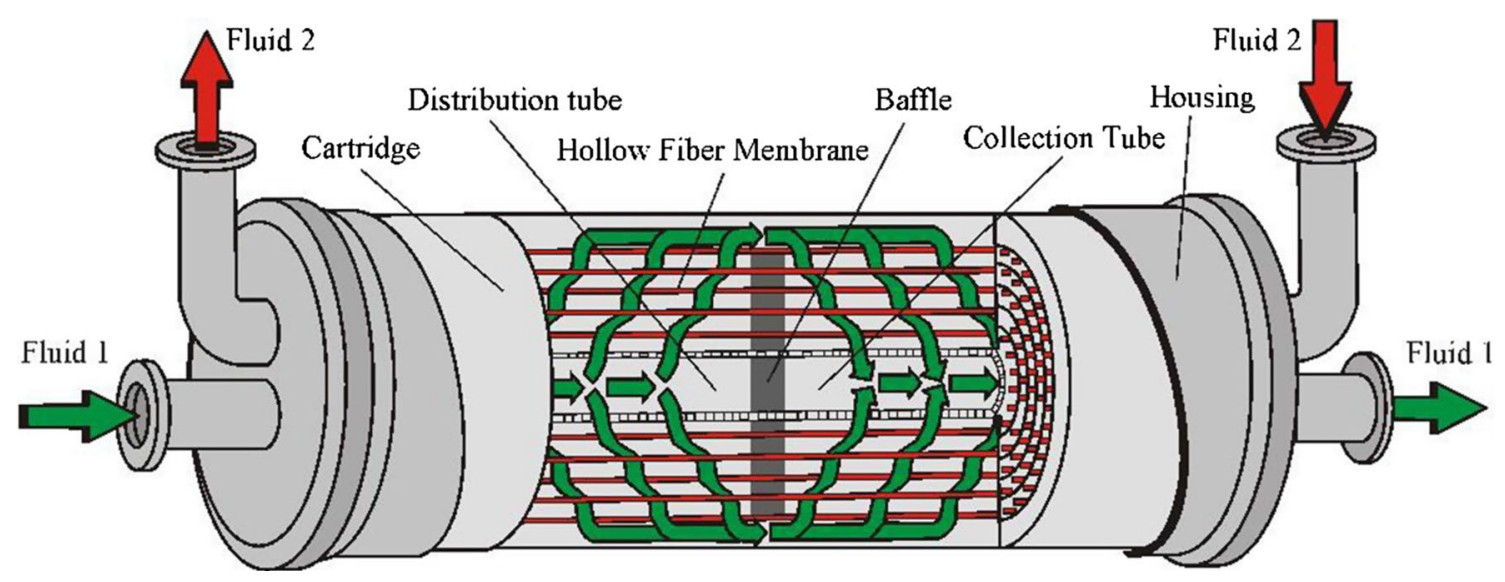

Fig. 5 Schematic of hollow fiber membrane contactor. The components of the membrane contactor and the direction of gas-liquid flow can be clearly seen from the structural drawing. Reproduced from Zhang (2015) 


\section{Effects of other conditions}

In addition to the previously mentioned factors, the connection mode of the membrane module, the direction of the gas-liquid flow, and the fluidity have a certain influence on the $\mathrm{CO}_{2}$ capture efficiency. Zhang et al. (2019) studied the effect of a single component and series of components on the $\mathrm{CO}_{2}$ capture efficiency in coalbed methane. According to the results, the decarburization rate of the serial module is evidently better than that of the single module. This is mainly due to the increase in the number of membrane modules, which leads to an increase in the effective membrane length and an increasing gas-liquid contact area and gas-liquid residence time in the membrane. This indirectly strengthens the mass transfer process between the two phases and improves the decarburization efficiency.

Boributh et al. (2011) compared the effects of single, serial, and parallel connection methods on the $\mathrm{CO}_{2}$ capture efficiency. The results show that the best absorption performance can be obtained with a serial connection. Moreover, Zhang et al. (2018b) studied biogas $\left(40 \% \mathrm{CO}_{2} / 60 \% \mathrm{CH}_{4}\right)$ $\mathrm{CO}_{2}$ separation and $\mathrm{CH}_{4}$ purification in a membrane contactor with an amine solution. By comparing the effects of single membrane module and membrane modules in series on the decarburization efficiency under equal conditions, they proved that the $\mathrm{CO}_{2}$ separation efficiency and $\mathrm{CH}_{4}$ purification efficiency increase by $24.4 \%$ and $9.8 \%$ with serial membrane modules, respectively. Simultaneously, they concluded that the efficiency of the countercurrent state increases by $38.9 \%$ and $25.6 \%$ compared with that of the downstream state, respectively. The previously mentioned studies demonstrate that the countercurrent flow mode can improve the $\mathrm{CO}_{2}$ capture efficiency owing to the influence of the driving force. Therefore, the countercurrent flow mode is currently mainly employed in membrane absorption systems.

The fluidity is mainly described by a laminar flow or turbulent flow. A gas-liquid contact is more sufficient owing to severe disturbances of the turbulences, which enhance the mass transfer between the gas and liquid phases, thus promoting the separation of $\mathrm{CO}_{2}$. This has been confirmed in Zhang et al. (2014a, c). In summary, the coalbed methane decarburization efficiency can be improved through a membrane module and countercurrent flow. The effects of different factors on $\mathrm{CO}_{2}$ capture efficiency are summarized in Table 4.

\section{Membrane absorption applied to other gases}

Qi and Cussler (1985) first proposed a method for absorbing $\mathrm{CO}_{2}$ with hollow fiber polypropylene (PP) membrane contactors. The method is widely applied because of its large gas-liquid contact area, fast mass transfer rate, no mist entrainment phenomenon, large operation flexibility, and small equipment. With the development of the membrane absorption technology in recent years, many research studies on the membrane absorption technology based on hollow fiber membranes have been conducted in China. Figure 6 presents the various application of $\mathrm{CO}_{2}$ separation from different gases.

As the main source of $\mathrm{CO}_{2}$, flue gas accounts for approximately $80 \%$ of the greenhouse gases (Sutanto et al. 2017). The main components of the flue gas are $\mathrm{CO}_{2}$ and $\mathrm{N}_{2}$, and the $\mathrm{CO}_{2}$ ratio is generally between 10 and $20 \mathrm{vol} \%$ (Masoumi et al. 2016; Zhang 2016). Therefore, capturing $\mathrm{CO}_{2}$ from flue gas is an effective method to control $\mathrm{CO}_{2}$ emissions. At present, the membrane absorption method is relatively mature
Fig. 6 Application of membrane separator for $\mathrm{CO}_{2}$ separation in different gases. The membrane separation method can be applied to a variety of gas decarburization treatments. The process of gas-liquid two-phase absorption in the contactor is also shown
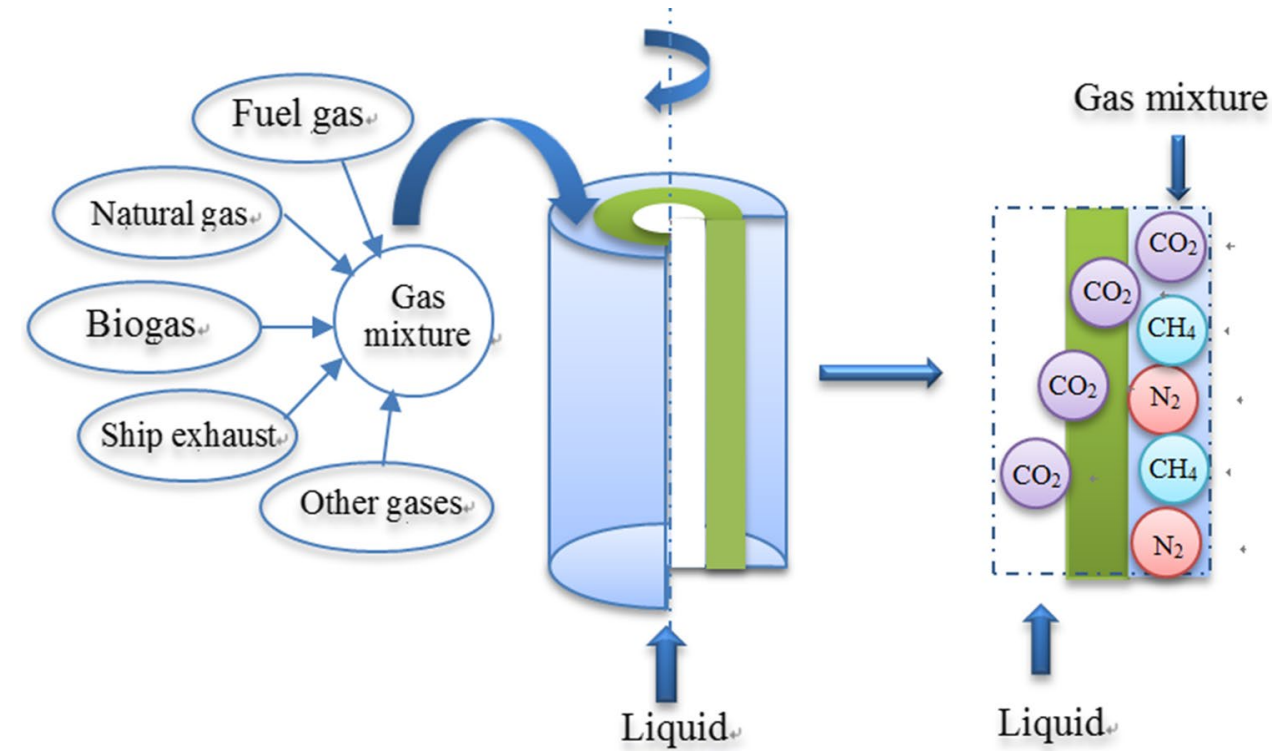
in the flue gas decarburization research field. Many studies have been carried out using the membrane absorption method to remove $\mathrm{CO}_{2}$ from flue gas (Chen and Cui 2012; Lee et al. 2019). Because the emitted flue gas has a relatively high temperature, a high-temperature-resistant membrane material is required for the membrane absorption. Therefore, to remove $\mathrm{CO}_{2}$ from flue gas through the membrane absorption method, future research will focus on the development of new high-temperature-resistant membrane materials.

China is a coal energy-consuming country, and energy shortages and environmental pollution will seriously hinder the sustainable development of the society (Medeiros et al. 2013). At present, natural gas is the fastest growing energy source in the world. However, natural gas contains acid gases such as $\mathrm{CO}_{2}$, which not only cause serious air pollution but also accelerate the corrosion of pipelines and equipment. Furthermore, $\mathrm{CO}_{2}$ reduces the calorific value of natural gas and increases transportation costs (Knoope et al. 2013). Therefore, natural gas must be purified to ensure the safety of natural gas storage, transportation, and use. The membrane absorption method is a process based on the combination of a conventional absorption method and membrane separation. The method does not require high precision and complicated operations of packed columns and an absorption tower when the $\mathrm{CO}_{2}$ is removed and enables highly efficient decarburization. Therefore, it is considered as a potential candidate that can be developed for natural gas purification (Fu et al. 2012). Many studies have been carried out on this technology (Faiz and Al-Marzouqi 2011; Kang et al. 2017; Rahim et al. 2015; Tang et al. 2014). However, owing to the high pressures required for the decarburization process of natural gas, the membrane absorption method suffers from many technical problems in the decarburization treatment. The membrane material has high requirements under high pressures, which might decrease the anti-wetting property of the membrane material. Thus, research on membrane materials with high-pressure resistances and anti-wetting properties would promote natural gas decarburization.

In response to the growing energy crisis, biogas is currently considered as a renewable energy source that can replace traditional fossil fuels (Amrei et al. 2014; Li et al. 2018c). The main components of biogas are $\mathrm{CO}_{2}$ and $\mathrm{CH}_{4}$, and the $\mathrm{CO}_{2}$ content is generally between $25 \mathrm{vol} \%$ and 55 vol\% (Scholz et al. 2013). However, initial biogas contains much $\mathrm{CO}_{2}$. Thus, the direct use will reduce the calorific value of biogas. It is essential to decarbonize biogas to improve its efficiency and make it a substitute for natural gas. Because membrane absorption exhibits a high decarburization efficiency, many researchers have used this technology to study biogas decarburization (Sutanto et al. 2017; Yan et al. 2014a, b, 2015a; Zhang et al. 2014c). However, the biogas phase has a higher $\mathrm{CO}_{2}$ content than coalbed methane and natural gas. Hence, the continuous 
research and development of high-efficiency absorbents to improve the biogas decarburization efficiency will become a research hot spot in the future.

The main emissions of ships include $\mathrm{CO}_{2}$, NOx, SOx, $\mathrm{CO}$, hydrocarbons, and particulate matter (Eyring 2005a). Emissions from ship exhaust increase the $\mathrm{SO}_{2}$ concentration in the atmosphere, which directly harms humans, marine life, and the stability of the entire ecosystem. Because the international community's requirements for environmental protection have increased, ship exhaust emission standards have become more stringent (Eyring 2005b). Owing to the limitations of narrow space in ship exhaust treatment, it is difficult to achieve flexible operation by traditional capture methods. By contrast, the membrane absorption methods are more suitable owing to their unique advantages (large gas-liquid contact area, flexible installation and operation, and simple equipment). At present, membrane absorption is applied to the $\mathrm{SO}_{2}$ capture from ship exhaust. Qiu et al. (2019) studied the optimization of the microstructures and geometries of hydrophobic ceramic membranes for $\mathrm{SO}_{2}$ absorption from ship exhaust gases. According to the results, the optimized efficiency can be increased by $16 \%$, and the optimal film thickness and inner film diameter are $1.0 \mathrm{~mm}$ and $4.0-6.0 \mathrm{~mm}$, respectively. So far, no scientific article has mentioned the use of membrane absorption to remove $\mathrm{CO}_{2}$ from ship exhaust gas. This will be the future development direction of the membrane absorption technology.

\section{Conclusion}

The membrane absorption method for coalbed methane decarburization is a key technology related to the application prospects of coalbed methane. A variety of separation techniques have been applied for coalbed methane decarburization. The membrane absorption method has the advantages of large gas-liquid contact areas, fast mass transfer rates, no mist entrainment phenomenon, a large operation flexibility, and small equipment. It has been widely applied for $\mathrm{CO}_{2}$ capture in flue gas, biogas, and natural gas. Although the gas composition and content of coalbed methane are different from those mentioned previously, the decarburization processes are similar. Therefore, we have summarized research studies with different $\mathrm{CO}_{2}$ and $\mathrm{CH}_{4}$ mixing ratios. The following conclusions can be drawn:

1. Increasing the temperature, concentration, and flow rate of the absorbent during the membrane absorption process and reducing the gas flow rate have a positive effect on the coalbed methane decarburization efficiency.

2. The newly applied solvents (e.g., amino acid salts and nanofluids) exhibit high decarburization efficiencies as absorbents. Furthermore, single absorbents can be mixed to achieve a better decarburization effect.

3. By changing the structure of the membrane contactor (e.g., increasing the effective membrane length and reducing the membrane wall thickness and membrane inner diameter), the $\mathrm{CO}_{2}$ can entirely react with the absorbent, which improves the $\mathrm{CO}_{2}$ capture efficiency.

4. The $\mathrm{CO}_{2}$ capture can be improved by changing the gasliquid flow state and flow direction, such as the flow state of the countercurrent and turbulent flow in the decarburization process.

At present, the membrane absorption method has good application prospects for purification treatments of coalbed methane, flue gas, natural gas, biogas, and ship exhaust. However, unresolved technical problems make large-scale industrial applications impossible and require further research. Based on the current and possible future applications of the membrane absorption technology to achieve large-scale applications, the following recommendations are given:

1. At present, the membrane absorption method mainly uses the simulated gas component for $\mathrm{CO}_{2}$ separation. However, because acid gases such as $\mathrm{H}_{2} \mathrm{~S}$ and $\mathrm{SO}_{2}$ can still interfere with the experimental results in the actual

Table 2 Development of absorbent usage for membrane absorption

\begin{tabular}{llll}
\hline Absorbent & Benefits & Drawbacks & References \\
\hline Water & Rich in resources and pollution-free & Low absorption efficiency & Marzouk et al. (2010) \\
Alkali & High absorption efficiency, large capacity & Strongly corrosive and non-renewable & Lin and Chu (2015) \\
Inorganic salt & Large absorption capacity and renewable & High-resolution energy consumption & Li et al. (2018c) \\
Amine & Fast chemical reaction rate, mature technology & Corrosive, high-resolution energy consumption & Amrei et al. (2014) \\
Amino acid salt & $\begin{array}{l}\text { Good compatibility with membrane, non-toxic, strong } \\
\text { thermal stability }\end{array}$ & Poor regeneration & Fang et al. (2015) \\
Nanofluids & $\begin{array}{c}\text { Large specific surface area and surface activity, high } \\
\text { absorption efficiency and stability }\end{array}$ & High equipment requirements and low output & Kim et al. (2018) \\
\hline
\end{tabular}




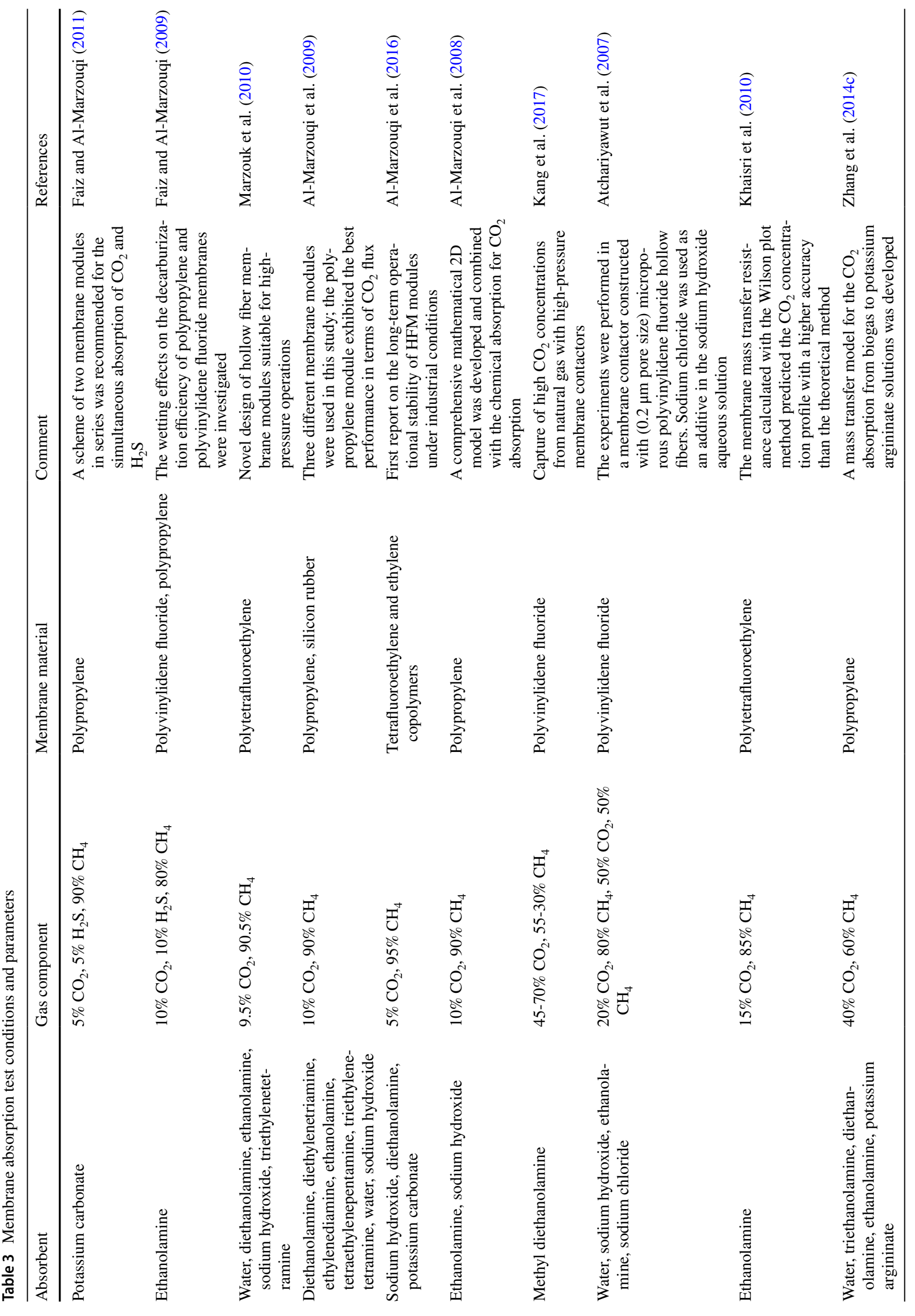


Table 4 Summary of the influence of different factors on $\mathrm{CO}_{2}$ capture efficiency

\begin{tabular}{|c|c|c|}
\hline Influencing factor & Effect on $\mathrm{CO}_{2}$ capture efficiency & References \\
\hline \multicolumn{3}{|l|}{ Gas phase } \\
\hline $\mathrm{CO}_{2}$ content & $\begin{array}{l}\text { A higher } \mathrm{CO}_{2} \text { concentration results in a decrease in the } \\
\mathrm{CO}_{2} \text { capture efficiency }\end{array}$ & Yan et al. (2007), Zhang (2016) \\
\hline Pressure & $\begin{array}{l}\text { Increasing gas pressure improves the } \mathrm{CO}_{2} \text { capture } \\
\text { efficiency }\end{array}$ & $\begin{array}{l}\text { Cozma et al. (2015), Dindore et al. (2004), Gao et al. } \\
\text { (2018) }\end{array}$ \\
\hline Flow rate & $\begin{array}{l}\text { The capture efficiency of } \mathrm{CO}_{2} \text { decreases with increas- } \\
\text { ing gas velocity }\end{array}$ & Daeho (2018), Yan et al. (2007), Zhang (2016) \\
\hline \multicolumn{3}{|l|}{ Liquid phase } \\
\hline Concentration & $\begin{array}{l}\text { As the liquid concentration increases, the } \mathrm{CO}_{2} \text { removal } \\
\text { efficiency is improved }\end{array}$ & Eslami et al. (2011), Lewis et al. (2011) \\
\hline Flow rate & $\begin{array}{l}\text { With increasing the absorbent flow rate, the } \mathrm{CO}_{2} \text { cap- } \\
\text { ture efficiency is improved }\end{array}$ & Ansaripour et al. (2018), Zhang et al. (2019) \\
\hline Absorbent temperature & $\begin{array}{l}\text { When increasing absorbent temperature, the } \mathrm{CO}_{2} \\
\text { capture efficiency increases }\end{array}$ & $\begin{array}{l}\text { Mansourizadeh and Matsuura (2010), Shirazian et al. } \\
\text { (2009) }\end{array}$ \\
\hline \multicolumn{3}{|c|}{ Membrane contactor structure } \\
\hline Membrane thickness & $\begin{array}{l}\text { Increasing the membrane thickness leads to a decrease } \\
\text { in the } \mathrm{CO}_{2} \text { capture efficiency }\end{array}$ & Rezakazemi et al. (2011) \\
\hline Module length & $\begin{array}{l}\text { Increasing the effective length of the fiber membrane } \\
\text { increases the } \mathrm{CO}_{2} \text { capture efficiency }\end{array}$ & Boributh et al. (2011) \\
\hline Inner diameter & $\begin{array}{l}\text { Reducing the inner diameter of the fiber membrane } \\
\text { results in an improvement in the } \mathrm{CO}_{2} \text { capture effi- } \\
\text { ciency }\end{array}$ & Eslami et al. (2011, Rajabzadeh et al. (2009) \\
\hline \multicolumn{3}{|l|}{ Other conditions } \\
\hline Gas-liquid flow direction & $\begin{array}{l}\text { The countercurrent flow mode can improve the } \mathrm{CO}_{2} \\
\text { capture efficiency }\end{array}$ & Zhang et al. (2018b) \\
\hline Fluidity & Turbulent flow can promote the $\mathrm{CO}_{2}$ capture efficiency & Zhang et al. (2014a) \\
\hline Module number & $\begin{array}{l}\text { A serial connection improves the } \mathrm{CO}_{2} \text { capture effi- } \\
\text { ciency }\end{array}$ & Boributh et al. (2011), Zhang et al. (2019) \\
\hline
\end{tabular}

gas composition, the influence of these interference factors on the degassing effect of the actual gas must be considered for more realistic simulation results.

2. The research on high-efficiency absorbents should focus on the absorption characteristics of novel amino acid salt solutions and nanofluids in membrane contactors owing to their higher chemical reaction rates and absorption efficiencies and because they are environmentally friendly, thermally stable, and membrane coated.

3. When developing a membrane absorption model, the model should be continuously optimized based on the differences in the absorbents, membrane materials, and other influencing factors. Furthermore, the kinetics and thermodynamics of the reaction of new absorbents with $\mathrm{CO}_{2}$ should be strengthened. Further comprehensive analyses should be conducted to optimize the conditions and maximize the $\mathrm{CO}_{2}$ absorption efficiency.

4. Expanding the application field of the $\mathrm{CO}_{2}$ absorption through the membrane absorption method: Ship exhaust contains much $\mathrm{CO}_{2}$. However, at present, researchers do not focus on the capture of $\mathrm{CO}_{2}$ from ship exhaust through membrane absorption.
Acknowledgements This work is supported by the Basic Science Center Program for Ordered Energy Conversion of the National Natural Science Foundation of China (No. 51888103), Liaoning Province Natural Science Fund Project Funding (No. 201602470), and Program for Liaoning Excellent Talents in University (No. LJQ2014038).

\section{References}

Al-Marzouqi MH, El-Naas MH, Marzouk SAM, Abdullatif N (2008) Modeling of chemical absorption of $\mathrm{CO}_{2}$ in membrane contactors. Sep Purif Technol 62(3):499-506. https://doi.org/10.1016/j. seppur.2008.02.009

Al-Marzouqi MH, Marzouk SAM, El-Naas MH, Abdullatif N (2009) Removal from $\mathrm{CO}_{2}-\mathrm{CH}_{4}$ gas mixture using different solvents and hollow fiber membranes. Ind Eng Chem Res 48(7):3600-3605. https://doi.org/10.1021/ie800977z

Al-Marzouqi MH, Marzouk SAM, Abdullatif N (2016) High pressure removal of acid gases using hollow fiber membrane contactors: further characterization and long-term operational stability. J Nat Gas Sci Eng 37:192-198. https://doi.org/10.1016/j.jngse 2016.11.039

Al-Saffar HB, Ozturk B, Hughes R (1997) A comparison of porous and non-porous gas-liquid membrane contactors for gas separation. Chem Eng Res Des 75(7):685-692. https://doi. org/10.1205/026387697524182 
Amrei SMHH, Memardoost S, Dehkordi AM (2014) Comprehensive modeling and CFD simulation of absorption of $\mathrm{CO}_{2}$ and $\mathrm{H}_{2} \mathrm{~S}$ by MEA solution in hollow fiber membrane reactors. AIChE $\mathrm{J}$ 60(2):657-672. https://doi.org/10.1002/aic.14286

Anand B, Rao Edward S, Rubin (2002) A technical, economic, and environmental assessment of amine-based $\mathrm{CO}_{2}$ capture technology for power plant greenhouse gas control. Environ Sci Technol 36(20):4467-4475. https://doi.org/10.1016/j.cherd.2017.11.024

Ansaripour M, Haghshenasfard M, Moheb A (2018) Experimental and numerical investigation of $\mathrm{CO}_{2}$ absorption using nanofluids in a hollow-fiber membrane contactor. Chem Eng Technol 41(2):367378. https://doi.org/10.1002/ceat.201700182

Atchariyawut S, Jiraratananon R, Wang R (2007) Separation of $\mathrm{CO}_{2}$ from $\mathrm{CH}_{4}$ by using gas-liquid membrane contacting process. J Membr Sci 304(1):163-172. https://doi.org/10.1016/j.memsc i.2007.07.030

Bhadra SJ, Farooq S (2011) Separation of methane-nitrogen mixture by pressure swing adsorption for natural gas upgrading. Ind Eng Chem Res 50(24):14030-14045. https://doi.org/10.1021/ie201 $237 \mathrm{x}$

Boributh S, Assabumrungrat S, Laosiripojana N, Jiraratananon R (2011) Effect of membrane module arrangement of gas-liquid membrane contacting process on $\mathrm{CO}_{2}$ absorption performance: a modeling study. J Membr Sci 372(1):75-86. https://doi. org/10.1016/j.memsci.2011.01.034

Boributh S, Jiraratananon R, Li K (2013) Analytical solutions for membrane wetting calculations based on log-normal and normal distribution functions for $\mathrm{CO}_{2}$ absorption by a hollow fiber membrane contactor. J Membr Sci 429(4):459-472. https://doi. org/10.1016/j.memsci.2012.11.074

Boucif N, Favre E, Roizard D (2008) $\mathrm{CO}_{2}$ capture in HFMM contactor with typical amine solutions: a numerical analysis. Chem Eng Sci 63(22):5375-5385. https://doi.org/10.1016/j.ces.2008.07.015

Chen J (2017) Study progress of concentrating technology of lowconcentration oxygen-containing coal-bed methane. Min Saf Environ Protect 44(1):94-97. https://doi.org/10.3969/j. issn.1008-4495.2017.01.024

Chen R, Cui LX (2012) Experimental study on the separation of $\mathrm{CO}_{2}$ from flue gas using hollow fiber membrane contactors with mixed absorbents. Adv Mater Res 573-574:18-22. https://doi. org/10.4028/www.scientific.net/amr.573-574.18

Chen J, Wen J (2015) The corrosion and degradation of amine solution in the coal bed methane decarburization process. Guangdong Chem Ind 42(12):45-46. https://doi.org/10.3969/j. issn.1007-1865(2015)12-0045-02

Chen W, Zhu B, Wang J, Youyi XU, Zhikang XU (2004) Study on hollow fibre membrane contactor for the separation of carbon dioxide from carbon dioxide-nitrogen mixture. Membr Sci Technol 24(1), 32-37. https://doi.org/10.16159/j.cnki.issn1 007-8924.2004.01.008

Cheng W, Hu X, Xie J, Zhao Y (2017) An intelligent gel designed to control the spontaneous combustion of coal: fire prevention and extinguishing properties. Fuel 210:826-835. https://doi. org/10.1016/j.coal.2012.05.01110.1016/j.fuel.2017.09.007

Cozma P, Wukovits W, Mămăligă I, Friedl A, Gavrilescu M (2015) Modeling and simulation of high pressure water scrubbing technology applied for biogas upgrading. Clean Technol Environ Policy 17(2):373-391. https://doi.org/10.1007/s10098-014-0787-7

Daeho K (2016) Development of a simulation model for the vacuum pressure swing adsorption process to sequester carbon dioxide from coalbed methane. Ind Eng Chem Res 55(4):1013-1023. https://doi.org/10.1021/acs.iecr.5b03824

Daeho K (2018) Development of a dynamic simulation model of a hollow fiber membrane module to sequester $\mathrm{CO}_{2}$ from coalbed methane. J Membr Sci 546:258-269. https://doi.org/10.1016/j. memsci.2017.09.040

Datta AK, Sen PK (2006) Optimization of membrane unit for removing carbon dioxide from natural gas. J Membr Sci 283(1):291-300. https://doi.org/10.1016/j.memsci.2006.06.043

Dindore VY, Brilman DWF, Feron PHM, Versteeg GF (2004) $\mathrm{CO}_{2}$ absorption at elevated pressures using a hollow fiber membrane contactor. J Membr Sci 235(1):99-109. https://doi. org/10.1016/j.memsci.2003.12.029

Ebner AD, Ritter JA (2009) State-of-the-art adsorption and membrane separation processes for carbon dioxide production from carbon dioxide emitting industries. Sep Sci Technol 44(6):1273-1421. https://doi.org/10.1080/014963909027333 14

Eslami S, Mousavi SM, Danesh S, Banazadeh H (2011) Modeling and simulation of $\mathrm{CO}_{2}$ removal from power plant flue gas by PG solution in a hollow fiber membrane contactor. Adv Eng Softw 42(8):612-620. https://doi.org/10.1016/j.advengsoft.2011.05.002

Eyring V, Köhler HW, Aardenne J, Lauer A (2005a) Emissions from international shipping: 1. The last 50 years. J Geophys Res 110(D17305):1-12. https://doi.org/10.1029/2004jd005619

Eyring V, Köhler HW, Lauer A, Lemper B (2005b) Emissions from international shipping: 2. Impact of future technologies on scenarios until 2050. J Geophys Res 110(D17306):1-18. https://doi. org/10.1029/2004jd005620

Faiz R, Al-Marzouqi M (2009) Mathematical modeling for the simultaneous absorption of $\mathrm{CO}_{2}$ and $\mathrm{H}_{2} \mathrm{~S}$ using MEA in hollow fiber membrane contactors. J Membr Sci 342(1):269-278. https://doi. org/10.1016/j.memsci.2009.06.050

Faiz R, Almarzouqi M (2010) $\mathrm{CO}_{2}$ removal from natural gas at high pressure using membrane contactors: model validation and membrane parametric studies. J Membr Sci 365(1):232-241. https:// doi.org/10.1016/j.memsci.2010.09.004

Faiz R, Al-Marzouqi M (2011) Insights on natural gas purification: simultaneous absorption of $\mathrm{CO}_{2}$ and $\mathrm{H}_{2} \mathrm{~S}$ using membrane contactors. Sep Purif Technol 76(3):351-361. https://doi. org/10.1016/j.seppur.2010.11.005

Fan C, Li S, Luo M, Du W, Yang Z (2017) Coal and gas outburst dynamic system. Int J Min Sci Technol 27(1):49-55. https://doi. org/10.1016/j.ijmst.2016.11.003

Fan Y, Deng C, Zhang X, Li F, Wang X, Qiao L (2018) Numerical study of $\mathrm{CO}_{2}$-enhanced coalbed methane recovery. Int J Greenhouse Gas Control 76:12-23. https://doi.org/10.1016/j.ijggc 2018.06.016

Fang M, Zhou X, Xiang Q, Cai D, Luo Z (2015) Kinetics of $\mathrm{CO}_{2}$ absorption in aqueous potassium L-prolinate solutions at elevated total pressure energy. Procedia 75(3):2293-2298. https:// doi.org/10.1016/j.egypro.2015.07.420

Fang H, Sang S, Liu S (2019) Numerical simulation of enhancing coalbed methane recovery by injecting $\mathrm{CO}_{2}$ with heat injection. Pet Sci 16(1):32-43. https://doi.org/10.1007/s12182-018-0291-5

Flores R, Flores R (2014) Coal and coalbed gas. Elsevier Inc, Amsterdam

Fu K, Sema T, Liang Z, Liu H, Na Y, Shi H, Idem R, Tontiwachwuthikul P (2012) Investigation of mass-transfer performance for $\mathrm{CO}_{2}$ absorption into diethylenetriamine (DETA) in a randomly packed column. Ind Eng Chem Res 51(37):12058-12064. https://doi. org/10.1021/ie300830h

Gabelman STH (1999) Hollow fiber membrane contactors. J Membr Sci 159(1-2):61-106. https://doi.org/10.1016/S0376 -7388(99)00040-X

Gao H, Liu S, Ge G, Xiao L, Liang Z (2018) Hybrid behavior and mass transfer performance for absorption of $\mathrm{CO}_{2}$ into aqueous DEEA/ PZ solutions in a hollow fiber membrane contactor. Sep Purif 
Technol 201:S1383586617334111. https://doi.org/10.1016/j. seppur.2018.03.027

Genceli EA, Sengur-Tasdemir R, Urper GM (2018) Effects of carboxylated multi-walled carbon nanotubes having different outer diameters on hollow fiber ultrafiltration membrane fabrication and characterization by electrochemical impedance spectroscopy. Polym Bull 75(6):1-27. https://doi.org/10.1016/j.egypr o.2011.01.194

Hajilary N, Rezakazemi M (2018) CFD modeling of $\mathrm{CO}_{2}$ capture by water-based nanofluids using hollow fiber membrane contactor. Int J Greenhouse Gas Control 77:88-95. https://doi. org/10.1016/j.ijggc.2018.08.002

Hao C, Cheng Y, Dong J, Liu H, Jiang Z, Tu Q (2018) Effect of silica sol on the sealing mechanism of a coalbed methane reservoir: new insights into enhancing the methane concentration and utilization rate. J Nat Gas Sci Eng 56:51-61. https://doi. org/10.1016/j.jngse.2018.05.032

Huang A, Chen L, Chen C, Tsai H, Tung K (2018) Carbon dioxide capture using an omniphobic membrane for a gas-liquid contacting process. J Membr Sci 556:227-237. https://doi.org/10.1016/j. memsci.2018.03.089

Ju W, Jiang B, Qin Y, Wu C, Wang G, Qu Z, Li M (2019) The present-day in-situ stress field within coalbed methane reservoirs, Yuwang Block, Laochang Basin, south China. Mar Pet Geol 102:61-73. https://doi.org/10.1016/j.marpetgeo.2018.12.030

Kaldis SP, Skodras G, Sakellaropoulos GP (2004) Energy and capital cost analysis of $\mathrm{CO}_{2}$ capture in coal IGCC processes via gas separation membranes. Fuel Process Technol 85(5):337-346. https://doi.org/10.1016/s0378-3820(03)00204-2

Kang G, Chan PZ, Saleh SBM, Cao Y (2017) Removal of high concentration $\mathrm{CO}_{2}$ from natural gas using high pressure membrane contactors. Int J Greenhouse Gas Control 60:1-9. https://doi. org/10.1016/j.ijggc.2017.03.003

Khaisri S, deMontigny D, Tontiwachwuthikul P, Jiraratananon R (2010) A mathematical model for gas absorption membrane contactors that studies the effect of partially wetted membranes. J Membr Sci 347(1):228-239. https://doi.org/10.1016/j.memsc i.2009.10.028

Kim M, Kim J (2018) Optimization model for the design and feasibility analysis of membrane-based gas separation systems for $\mathrm{CO}_{2}$ enhanced coal bed methane $\left(\mathrm{CO}_{2}\right.$-ECBM) applications. Chem Eng Res Des 132:853-864. https://doi.org/10.1016/j.cherd .2018 .02 .036

Kim S, Ko D, Mun J, Kim TH, Kim J (2017) Techno-economic evaluation of gas separation processes for long-term operation of $\mathrm{CO}_{2}$ injected enhanced coalbed methane (ECBM). Korean J Chem Eng 35(1):1-15. https://doi.org/10.1007/s11814-017-0261-4

Kim S, Jeong M, Lee JW, Kim SY, Choi CK, Kang YT (2018) Development of nanoemulsion $\mathrm{CO}_{2}$ absorbents for mass transfer performance enhancement. Int Commun Heat Mass Transfer 94:24-31. https://doi.org/10.1016/j.icheatmasstrans fer.2018.03.012

Knoope MMJ, Ramírez A, Faaij APC (2013) A state-of-the-art review of techno-economic models predicting the costs of $\mathrm{CO}_{2}$ pipeline transport. Int J Greenhouse Gas Control 16(10):241-270. https ://doi.org/10.1016/j.ijggc.2013.01.005

Lee S, Yun S, Kim J-K (2019) Development of novel sub-ambient membrane systems for energy-efficient post-combustion $\mathrm{CO}_{2}$ capture. Appl Energy 238:1060-1073. https://doi.org/10.1016/j. apenergy.2019.01.130

Lei L, Yao C (2013) Simulation study on $\mathrm{CO}_{2}$ removal technology from coal- bed methane with alkamine method. Min Saf Environ Prot 6:1-3. https://doi.org/10.3969/j.issn.1008-4495.2013.06.001

Lewis T, Faubel DM, Winter DB, Hemminger PDJC (2011) $\mathrm{CO}_{2}$ capture in amine-based aqueous solution: role of the gas-solution interface. Angew Chem Int Ed Engl. https://doi.org/10.1002/ ange. 201101250

Li JL, Chen BH (2005) Review of $\mathrm{CO}_{2}$ absorption using chemical solvents in hollow fiber membrane contactors. Sep Purif Technol 41(2):109-122. https://doi.org/10.1016/j.seppur.2004.09.008

Li H, Lau HC, Huang S (2018a) China's coalbed methane development: a review of the challenges and opportunities in subsurface and surface engineering. J Petrol Sci Eng 166:621-635. https:// doi.org/10.1016/j.petrol.2018.03.047

Li X, Kang Y, Zhou L (2018b) Investigation of gas displacement efficiency and storage capability for enhanced $\mathrm{CH}_{4}$ recovery and $\mathrm{CO}_{2}$ sequestration. J Petrol Sci Eng 169:485-493. https://doi. org/10.1016/j.petrol.2018.06.006

Li Y, Wang LA, Zhang Z, Hu X, Yin C, Cheng Z (2018c) Carbon dioxide absorption from biogas by amino acid salt promoted potassium carbonate solutions in a hollow fiber membrane contactor: a numerical study. Energy Fuels 32(3):3637-3646. https://doi. org/10.1021/acs.energyfuels.7b03616

Li H, Li G, Kang J, Zhou F, Deng J (2019) Analytical model and experimental investigation of the adsorption thermodynamics of coalbed methane. Adsorption 25(2):201-216. https://doi. org/10.1007/s10450-019-00028-2

Liang W, Zhang Z, Zhao B, Zhang H, Lu X, Qin Y (2013) Effect of long-term operation on the performance of polypropylene and polyvinylidene fluoride membrane contactors for $\mathrm{CO}_{2}$ absorption. Sep Purif Technol 116(37):300-306. https://doi. org/10.1016/j.seppur.2013.05.051

Lin CC, Chu CR (2015) Feasibility of carbon dioxide absorption by $\mathrm{NaOH}$ solution in a rotating packed bed with blade packings. Int J Greenhouse Gas Control 42:117-123. https://doi.org/10.1016/j. ijggc.2015.07.035

Liu Z, Cheng Y, Dong J, Jiang J, Wang L, Li W (2018a) Master role conversion between diffusion and seepage on coalbed methane production: implications for adjusting suction pressure on extraction borehole. Fuel 223:373-384. https://doi.org/10.1016/j. fuel.2018.03.047

Liu Z, Pan Z, Zhang Z, Liu P, Shang L, Li B (2018b) Effect of porous media and sodium dodecyl sulphate complex system on methane hydrate formation. Energy Fuels 32(5):5736-5749. https://doi. org/10.1021/acs.energyfuels.8b00041

Liu SS, Guo X, Ren J (2018c) Comprehensive utilization status of coalbed methane in China. Mod Chem Ind 38(3), 4-8. https:// doi.org/10.16606/j.cnki.issn0253-4320.2018.03.002

Luis P, Van Gerven T, Van der Bruggen B (2012) Recent developments in membrane-based technologies for $\mathrm{CO}_{2}$ capture. Prog Energy Combust Sci 38(3):419-448. https://doi.org/10.1016/j. pecs.2012.01.004

Lv Y, Yu X, Tu S-T, Yan J, Dahlquist E (2012a) Experimental studies on simultaneous removal of $\mathrm{CO}_{2}$ and $\mathrm{SO}_{2}$ in a polypropylene hollow fiber membrane contactor. Appl Energy 97:283-288. https:// doi.org/10.1016/j.apenergy.2012.01.034

Lv YX, Xu CQ, Yan GH, Guo DY, Xiao Q (2012b) A review on $\mathrm{CO}_{2}$ capture using membrane gas absorption technology. Adv Mater Res 616-618:1541-1545. https://doi.org/10.4028/www.scientific .net/AMR.616-618.1541

Lv Q, Xiaosen L, Chungang X, Zhaoyang C, Gang L (2013) Progress of purification technology for low concentration coal-bed methane. Chem Ind Eng Prog 32(6):1267-1277. https://doi. org/10.3969/j.issn.1000-6613.2013.06.011

Mallick N, Prabu V (2017) Energy analysis on coalbed methane (CBM) coupled power systems. $\mathrm{J} \mathrm{CO}_{2}$ Utilization 19:16-27. https://doi. org/10.1016/j.jcou.2017.02.012

Mansourizadeh A (2012) Experimental study of $\mathrm{CO}_{2}$ absorption/stripping via PVDF hollow fiber membrane contactor. Chem Eng Res Des 90(4):555-562. https://doi.org/10.1016/j.cherd.2011.08.017 
Mansourizadeh I, Matsuura AF (2010) Effect of operating conditions on the physical and chemical $\mathrm{CO}_{2}$ absorption through the PVDF hollow fiber membrane contactor. J Membr Sci 353(1):192-200. https://doi.org/10.1016/j.memsci.2010.02.054

Mansourizadeh A, Ismail AF, Matsuura T (2010) Effect of operating conditions on the physical and chemical $\mathrm{CO}_{2}$ absorption through the PVDF hollow fiber membrane contactor. J Membr Sci 353(1):192-200. https://doi.org/10.1016/j.memsci.2010.02.054

Marzouk SAM, Al-Marzouqi MH, El-Naas MH, Abdullatif N, Ismail ZM (2010) Removal of carbon dioxide from pressurized $\mathrm{CO}_{2}-\mathrm{CH}_{4}$ gas mixture using hollow fiber membrane contactors. J Membr Sci 351(1):21-27. https://doi.org/10.1016/j.memsc i.2010.01.023

Masoumi S, Rahimpour MR, Mehdipour M (2016) Removal of carbon dioxide by aqueous amino acid salts using hollow fiber membrane contactors. J $\mathrm{CO}_{2}$ Utilization 16:42-49. https://doi. org/10.1016/j.jcou.2016.05.008

Medeiros JLD, Grava WM, Nascimento JF, Araújo ODQF, Nakao A (2013) Simulation of an off-shore natural gas purification process for $\mathrm{CO}_{2}$ removal with gas-liquid contactors employing aqueous solutions of ethanolamines. Comput Aided Chem Eng 52(22):7074-7089. https://doi.org/10.1016/B978-0-444-59507 $-2.50151-7$

Medina-Gonzalez Y, Lasseuguette E, Rouch JC, Remigy JC (2012) Improving PVDF hollow fiber membranes for $\mathrm{CO}_{2}$ gas capture. Sep Sci Technol 47(11):1596-1605. https://doi. org/10.1080/01496395.2012.658942

Meng F, Wang H, Liao C (2018) Research progress of hydrate separation technology for biogas purification. Chem Ind Eng Prog 37(1), 68-79. https://doi.org/10.16085/j.issn.1000-6613.2017-0798

Mesbah M, Momeni M, Soroush E, Shahsavari S, Galledari SA (2019) Theoretical study of $\mathrm{CO}_{2}$ separation from $\mathrm{CO}_{2} / \mathrm{CH}_{4}$ gaseous mixture using 2-methylpiperazine-promoted potassium carbonate through hollow fiber membrane contactor. J Environ Chem Eng 7(1):102781. https://doi.org/10.1016/j.jece.2018.11.026

Moore TA (2012) Coalbed methane: a review. Int J Coal Geol 101(6):36-81. https://doi.org/10.1016/j.coal.2012.05.011

Nakhjiri AT, Heydarinasab A, Bakhtiari O, Mohammadi T (2018) The effect of membrane pores wettability on $\mathrm{CO}_{2}$ removal from $\mathrm{CO}_{2} / \mathrm{CH}_{4}$ gaseous mixture using $\mathrm{NaOH}$, MEA and TEA liquid absorbents in hollow fiber membrane contactor. Chin J Chem Eng 26(9):1845-1861. https://doi.org/10.1016/j.cjche .2017.12.012

Pan Z, Liu Z, Zhang Z, Shang L, Ma S (2018) Effect of silica sand size and saturation on methane hydrate formation in the presence of SDS. J Natl Gas Sci Eng 56:266-280. https://doi.org/10.1016/j. jngse.2018.06.018

Pashaei H, Ghaemi A, Nasiri M (2016) Modeling and experimental study on the solubility and mass transfer of $\mathrm{CO}_{2}$ into aqueous DEA solution using a stirrer bubble column. RSC Adv 6(109):108075-108092. https://doi.org/10.1039/c6ra22589f

Qi Z, Cussler E (1985) Microporous hollow fibers for gas absorption II: mass transfer across the membrane. J Membr Sci 23(3):333-345. https://doi.org/10.1016/S0376-7388(00)83150-6

Qin Y, Ye JP (2015) A review on development of CBM industry in China. Paper presented at the AAPG Asia pacific geoscience technology workshop (GTW) opportunities and advancements in coal bed methane in the Asia Pacific, Brisbane, Queensland, Australia, pp 12-13. https://doi.org/10.1016/j.coal.2012.05.01110 .1016/j.fuel.2016.03.065

Qiu M, Kong X, Fu K, Han S, Gao X, Chen X, Fan Y (2019) Optimization of microstructure and geometry of hydrophobic ceramic membrane for $\mathrm{SO}_{2}$ absorption from ship exhaust. AIChE J 65(1):409-420. https://doi.org/10.1002/aic.16416

Rahim NA, Ghasem N, Al-Marzouqi M (2015) Absorption of $\mathrm{CO}_{2}$ from natural gas using different amino acid salt solutions and regeneration using hollow fiber membrane contactors. J Nat Gas Sci Eng 26:108-117. https://doi.org/10.1016/j.jngse.2015.06.010

Rajabzadeh S, Yoshimoto S, Teramoto M, Al-Marzouqi M, Matsuyama $\mathrm{H}$ (2009) $\mathrm{CO}_{2}$ absorption by using PVDF hollow fiber membrane contactors with various membrane structures. Sep Purif Technol 69(2):210-220. https://doi.org/10.1016/j.seppur.2009.07.021

Razavi SMR, Razavi SMJ, Miri T, Shirazian S (2013) CFD simulation of $\mathrm{CO}_{2}$ capture from gas mixtures in nanoporous membranes by solution of 2-amino-2-methyl-1-propanol and piperazine. Int J Greenhouse Gas Control 15(4):142-149. https://doi. org/10.1016/j.ijggc.2013.02.011

Rezakazemi M, Niazi Z, Mirfendereski M, Shirazian S, Mohammadi T, Pak A (2011) CFD simulation of natural gas sweetening in a gas-liquid hollow-fiber membrane contactor. Chem Eng J 168(3):1217-1226. https://doi.org/10.1016/j.cej.2011.02.019

Rezakazemi M, Darabi M, Soroush E, Mesbah M (2019) $\mathrm{CO}_{2}$ absorption enhancement by water-based nanofluids of CNT and $\mathrm{SiO}_{2}$ using hollow-fiber membrane contactor. Sep Purif Technol 210:920-926. https://doi.org/10.1016/j.seppur.2018.09.005

Sarhosis V, Jaya AA, Thomas HR (2016) Economic modelling for coal bed methane production and electricity generation from deep virgin coal seams. Energy 107:580-594. https://doi.org/10.1016/j. energy.2016.04.056

Scholz M, Melin T, Wessling M (2013) Transforming biogas into biomethane using membrane technology. Renew Sustain Energy Rev 17:199-212. https://doi.org/10.1016/j.rser.2012.08.009

Shirazian S, Moghadassi A, Moradi S (2009) Numerical simulation of mass transfer in gas-liquid hollow fiber membrane contactors for laminar flow conditions. Simul Model Pract Theory 17(4):708718. https://doi.org/10.1016/j.simpat.2008.12.002

Simons K, Nijmeijer K, Mengers H, Brilman W, Wessling M (2010) Highly selective amino acid salt solutions as absorption liquid for $\mathrm{CO}_{2}$ capture in gas-liquid membrane contactors. Chemsuschem 3(8):939-947. https://doi.org/10.1002/cssc.201000076

Stowe HM, Hwang GS (2017) Molecular insights into the enhanced rate of $\mathrm{CO}_{2}$ absorption to produce bicarbonate in aqueous 2-amino2-methyl-1-propanol. Phys Chem Chem Phys 19(47):32116. https://doi.org/10.1039/c7cp05580c

Su X, Wang Q, Lin H, Song J, Guo H (2018) A combined stimulation technology for coalbed methane wells: Part 2. Application. Fuel 233:539-551. https://doi.org/10.1016/j.fuel.2018.06.086

Sun H, Zhu HM (2009) Simulation and analysis of a liquefaction and separation process of low concentration CBM. Cryogenics 37(8):21-23. https://doi.org/10.1016/j.memsci.2009.10.028

Sutanto S, Dijkstra JW, Pieterse JAZ, Boon J, Hauwert P, Brilman DWF (2017) $\mathrm{CO}_{2}$ removal from biogas with supported amine sorbents: first technical evaluation based on experimental data. Sep Purif Technol 184:12-25. https://doi.org/10.1016/j.seppu r.2017.04.030

Taheri M, Mohebbi A, Hashemipour H, Rashidi AM (2016) Simultaneous absorption of carbon dioxide $\left(\mathrm{CO}_{2}\right)$ and hydrogen sulfide $\left(\mathrm{H}_{2} \mathrm{~S}\right)$ from $\mathrm{CO}_{2}-\mathrm{H}_{2} \mathrm{~S}-\mathrm{CH}_{4}$ gas mixture using amine-based nanofluids in a wetted wall column. J Nat Gas Sci Eng 28:410-417. https://doi.org/10.1016/j.jngse.2015.12.014

Tang J, Jie C, Guo Q, Hao F, Hua Y, Jie C, Yue W, Zeng D (2014) Kinetics research on mixed solvents of MDEA and enamine in natural gas decarbonization process. J Nat Gas Sci Eng 19(19):52-57. https://doi.org/10.1016/j.jngse.2014.04.014

Tao L, Xiao P, Qader A, Webley PA (2019) $\mathrm{CO}_{2}$ capture from high concentration $\mathrm{CO}_{2}$ natural gas by pressure swing adsorption at the $\mathrm{CO}_{2} \mathrm{CRC}$ Otway site, Australia. Int J Greenhouse Gas Control 83:1-10. https://doi.org/10.1016/j.ijggc.2018.12.025

Wan YF (2014) Simulation analysis of CBM decarburization process. AIChE J 34(7):149-152. https://doi.org/10.1002/aic.16416 
Wang Y, Lang X, Fan S (2013) Hydrate capture $\mathrm{CO}_{2}$ from shifted synthesis gas, flue gas and sour natural gas or biogas. J Energy Chem 21(1):39-47. https://doi.org/10.1016/S2095-4956(13)60004-2

Wang C, Zhang W, Xiong Y, Lu X (2014) Study on test parameters of oxygen liquefaction cold box for low-concentration coal-bed methane. Min Saf Environ Protect 41(4):26-28

Warmuzinski K (2008) Harnessing methane emissions from coal mining. Process Saf Environ Prot 86(5):315-320. https://doi. org/10.1016/j.psep.2008.04.003

Wu XN, Wang L, Zhang ZH, Li WY, Guo XF (2012) Experimental studies on $\mathrm{CO}_{2}$ absorption in immersed hollow fiber membrane contactor. Appl Mech Mater 209-211:1571-1575. https://doi. org/10.4028/www.scientific.net/AMM.209-211.1571

Xu J, Wu H, Wang Z, Qiao Z, Zhao S, Wang J (2018) Recent advances on the membrane processes for $\mathrm{CO}_{2}$ separation. Chin J Chem Eng 26(11):2280-2291. https://doi.org/10.1016/j.cjche.2018.08.020

Yan J, Zhang Z (2019) Carbon capture, utilization and storage (CCUS). Appl Energy 235:1289-1299. https://doi.org/10.1016/j.apene rgy.2018.11.019

Yan S, Fang M, Zhang W, Wang S, Xu Z, Luo Z, Cen K (2007) Experimental study on the separation of $\mathrm{CO}_{2}$ from flue gas using hollow fiber membrane contactors without wetting. Fuel Process Technol 88(5):501-511. https://doi.org/10.1016/j.fuproc.2006.12.007

Yan S, He Q, Zhao S, Wang Y, Ping A (2014a) Biogas upgrading by $\mathrm{CO}_{2}$ removal with a highly selective natural amino acid salt in gas-liquid membrane contactor. Chem Eng Process 85:125-135. https://doi.org/10.1016/j.cep.2014.08.009

Yan Y, Zhang Z, Li Z, Chen Y, Qiang T (2014b) Dynamic modeling of biogas upgrading in hollow fiber membrane contactors. Energy Fuels 28(9):5745-5755. https://doi.org/10.1021/ef501435q

Yan S, He Q, Zhao S, Zhai H, Cao M, Ai P (2015a) $\mathrm{CO}_{2}$ removal from biogas by using green amino acid salts: performance evaluation. Fuel Process Technol 129(129):203-212. https://doi. org/10.1016/j.fuproc.2014.09.019

Yan Y, Zhien Z, Shuiping Y, Ju S-X, Li Z, Z (2015b) Simulation on the structure effects of hollow fiber membrane on $\mathrm{CO}_{2}$ removal from flue gas. J Chem Eng Chin Univ 29(2):452-457. https://doi. org/10.3969/j.issn.1003-9015.2015.02.032

Yuan S, Yang Z, Ji X, Chen Y, Sun Y, Lu X (2017) $\mathrm{CO}_{2}$ absorption in mixed aqueous solution of MDEA and cholinium glycinate. Energy Fuels 31(7):7325-7333. https://doi.org/10.1021/acs.energ yfuels.7b00927

Zeng J, Cao, XX, Wan, XH, Li, YF (2017) Application research of a new composite decarburization method for coalbed methane China. Chem Trade 9(8):216-220. https://doi.org/10.1016/j. apenergy.2018.09.189

Zhang $\mathrm{Z}$ (2015) $\mathrm{CO}_{2}$ absorption in a hollow fiber membrane contactor and its sorption characteristics in a PVA facilitated transport membrane. Chongqing University, Chongqing

Zhang Z (2016) Comparisons of various absorbent effects on carbon dioxide capture in membrane gas absorption (MGA) process. J Nat Gas Sci Eng 31:589-595. https://doi.org/10.1016/j.jngse .2016 .03 .052
Zhang Z, Cai J, Chen F, Li H, Zhang W, Qi W (2018a) Progress in enhancement of $\mathrm{CO}_{2}$ absorption by nanofluids: a mini review of mechanisms and current status. Renew Energy 118:527-535. https://doi.org/10.1016/j.renene.2017.11.031

Zhang Z, Chen F, Rezakazemi M, Zhang W, Lu C, Chang H, Quan $\mathrm{X}$ (2018b) Modeling of a $\mathrm{CO}_{2}$-piperazine-membrane absorption system. Chem Eng Res Des 131:375-384. https://doi. org/10.1016/j.cherd.2017.11.024

Zhang N, Pan Z, Zhang L, Zhang Z (2019) Decarburization characteristics of coalbed methane by membrane separation technology. Fuel 242:470-478. https://doi.org/10.1016/j.fuel.2019.01.087

Zhang WF, Shu JH (2014) Experimental study of $\mathrm{CO}_{2}$ sequestration using glycinate-TEA. Appl Mech Mater 522-524:396-400. https ://doi.org/10.4028/www.scientific.net/AMM.522-524.396

Zhang Z, Wu X, Liang W, Zhao B, Li J, Zhang H (2017) Wetting mechanism of a PVDF hollow fiber membrane in immersed membrane contactors for $\mathrm{CO}_{2}$ capture in the presence of monoethanolamine. RSC Adv 7(22):13451-13457. https://doi.org/10.1039/C6RA2 $8563 \mathrm{E}$

Zhang Z, Yan Y, Chen Y, Zhang L (2014a) Investigation of $\mathrm{CO}_{2}$ absorption in methyldiethanolamine and 2-(1-piperazinyl)-ethylamine using hollow fiber membrane contactors: Part C. Effect of operating variables. J Nat Gas Sci Eng 20:58-66. https://doi. org/10.1016/j.jngse.2014.06.008

Zhang Z, Yan Y, Li Z, Chen Y, Ju S (2014b) CFD investigation of $\mathrm{CO}_{2}$ capture by methyldiethanolamine and 2-(1-piperazinyl)-ethylamine in membranes: Part B. Effect of membrane properties. J Nat Gas Sci Eng 19(19):311-316. https://doi.org/10.1016/j.jngse 2014.05.023

Zhang Z, Yan Y, Zhang L, Chen Y, Ran J, Pu G, Qin C (2014c) Theoretical study on $\mathrm{CO}_{2}$ absorption from biogas by membrane contactors: effect of operating parameters. Ind Eng Chem Res 53(36):14075-14083. https://doi.org/10.1021/ie502830k

Zheng D, Zhao D (2018) Research on development policy of coalbed methane industry in China's coal mining areas. Coal Econ Res 38(11), 60-65. https://doi.org/10.13202/j.cnki.cer.2018.11.011

Zhong D, He S, Yan J, Ding K, Yang C (2014) An experimental study of using hydrate formation to enhance the methane recovery of low-concentration CBM. Nat Gas Ind 34(8):123-128. https://doi. org/10.3787/j.issn.1000-0976.2014.08.020

Zhou H, Yang Q, Cheng Y, Ge C, Chen J (2014) Methane drainage and utilization in coal mines with strong coal and gas outburst dangers: a case study in Luling mine, China. J Nat Gas Sci Eng 20:357-365. https://doi.org/10.1016/j.jngse.2014.07.023 